\title{
FORUM
}

\section{Microbial Control of Arthropod Pests of Tropical Tree Fruits}

\author{
Claudia Dolinski ${ }^{1}$ and Lawrence A. Lacey ${ }^{2}$ \\ ${ }^{1}$ Univ. Estadual do Norte Fluminense/CCTA/LEF, Av. Alberto Lamego, 2000, Campos dos Goytacazes, RJ, Brazil \\ ${ }^{2}$ Yakima Agricultural Research Laboratory, USDA-ARS, 5230 Konnowac Pass Rd., Wapato, WA, 98951, USA
}

Neotropical Entomology 36(2):161-179 (2007)

\section{Controle Microbiano de Artrópodes-Praga em Fruteiras Tropicais}

\begin{abstract}
RESUMO - Muitos insetos e ácaros atacam fruteiras nos trópicos. O método tradicional para controlar a maioria dessas pragas é a aplicação de inseticidas químicos. A crescente preocupação sobre os efeitos negativos desses produtos vem encorajando o desenvolvimento de alternativas. Agentes do controle biológico aplicados de forma inundativa ou inoculativa têm sido pesquisados como método de controle alternativo para uma variedade de pragas em grande número de culturas, incluindo fruteiras tropicais. A maioria das pesquisas e aplicações em fruteiras tropicais tem sido feita em citros, banana, côco e manga. Especificamente, há vários casos de sucesso em citros para diferentes ácaros e insetos. Em banana, o controle do moleque-da-bananeira, Cosmopolites sordidus Germar (Coleoptera: Curculionidae) com nematóides e fungus também é considerado de sucesso. Oryctes rhinoceros (L.) (Coleoptera: Scarabaeidae) é uma das principais pragas em côco e um dos mais importantes exemplos de controle biológico clássico por vírus não-ocluso. As pragas-chave em manga que têm sido controladas com diferentes agentes de controle microbiano são as moscas-das-frutas (Diptera: Tephritidae), com nematóides e fungos, o gorgulho-da-manga, Sternochetus mangiferae (Fabricius) (Coleoptera: Curculionidae), com fungos, e vários hemípteros com fungo. O controle microbiano de pragas tem sido bem sucedido também em goiaba, mamão e abacaxi. O desafio que se vislumbra para a maior aplicabilidade dessas tecnologias é o desenvolvimento de combinações compatíveis entre entomopatógenos, predadores e parasitóides juntamente com outras técnicas de controle.
\end{abstract}

PALAVRAS-CHAVE: Bactéria, vírus, fungo, nematóide

\begin{abstract}
A multitude of insects and mites attack fruit crops throughout the tropics. The traditional method for controlling most of these pests is the application of chemical pesticides. Growing concern on the negative environmental effects has encouraged the development of alternatives. Inundatively and inoculatively applied microbial control agents (virus, bacteria, fungi, and entomopathogenic nematodes) have been developed as alternative control methods of a wide variety of arthropods including tropical fruit pests. The majority of the research and applications in tropical fruit agroecosystems has been conducted in citrus, banana, coconut, and mango. Successful microbial control initiatives of citrus pests and mites have been reported. Microbial control of arthropod pests of banana includes banana weevil, Cosmopolites sordidus Germar (Coleoptera: Curculionidae) (with EPNs and fungi) among others Oryctes rhinoceros (L.) is one of the most important pests of coconut and one of the most successful uses of non-occluded virus for classical biological control. Key pests of mango that have been controlled with microbial control agents include fruit flies (Diptera: Tephritidae) (with EPNs and fungi), and other pests. Also successful is the microbial control of arthropod pests of guava, papaya and pineapple. The challenge towards a broader application of entomopathogens is the development of successful combinations of entomopathogens, predators, and parasitoids along with other interventions to produce effective and sustainable pest management.
\end{abstract}

KEY WORDS: Bacteria, virus, fungus, nematode

A multitude of insect and mite species are pests of tree fruit world wide. The traditional method for controlling most of these pests is the application of chemical pesticides, which has generated complex problems including: insecticide resistance; outbreaks of secondary pests normally held in check by natural enemies; safety risks for humans and wild and domestic animals; contamination of ground water and riparian habitats; and decrease in biodiversity. Growing concern over the environmental effects of pesticides has encouraged the development of alternatives to broad- 
spectrum pesticides. Natural pathogens of arthropods often play an important role in the regulation of insect and mite populations in agroecosystems (Ignoffo 1985, Steinkraus 2007). However, their main impact on pests may occur after economic thresholds are surpassed. Inundatively or inoculatively applied microbial control agents (viruses, bacteria, fungi, and nematodes) have been developed as alternative control methods for a wide variety arthropod pests (Alves 1998a, Lacey et al. 2001, Kaya and Lacey 2007), which include pests of tropical tree fruit. In this review we will explore the use of entomopathogens and nematodes for control of insects and mites of tropical fruit.

\section{Candidate Entomopathogens}

Viruses. Many viruses have been identified from hundreds of arthropod species. For most of them, those with particles occluded in protein bodies (OBs) [Baculoviridae, Entomopoxviridae, Reoviridae (Cypoviruses)] have been used successfully in microbial control programs. The Baculoviridae (nucleopolyhedroviruses and granuloviruses) are the most studied and used as microbial control agents (Hunter-Fujita et al.1998, Moscardi 1999, Cory \& Evans 2007). They are normally transmitted per os and gain access to host tissues via the midgut where the OBs that surround the virus rods are dissolved. The currently unclassified virus of Oryctes rhinoceros L. is the most successfully used non-occluded virus. Viruses comprise some of the most host-specific entomopathogens but their main drawbacks are the requirement for in vivo production and their sensitivity to ultra-violet degradation.

Bacteria. Although several species of bacteria have been used as microbial control agents of a variety of insects, only Bacillus thuringiensis Berliner (Bt) has been used for practical pest control. It is the most widely used inundatively applied microbial control agent (Lacey et al. 2001). Several isolates of $\mathrm{Bt}$ are commercially produced with activity against Lepidoptera, Coleoptera, and Diptera. The safety of Bt for applicators and vertebrate and invertebrate non-target organisms is well documented (Lacey \& Siegel 2000). Its insecticidal activity is associated with delta-endotoxins located in parasporal inclusion bodies (or parasporal crystals) that are produced at sporulation and must be ingested by the target organism in order to be active. A limiting factor of $\mathrm{Bt}$ is its fairly narrow host range.

Fungi. The majority of fungi that naturally regulate insect and mite populations is in the order Hypocreales (Ascomycetes, including the vast majority of conidial entomopathogens in more than two dozen genera formerly classified among either the Hyphomycetes or Fungi Imperfecti) and Entomophthorales. The latter are difficult or impossible to mass-produce and, hence, they have not been commercially produced or applied inundatively on a large scale. On the other hand, several asexually reproducing species in the Hypocreales are amenable to mass production and commercialization. The most studied for control of insects and mites belong to the genera Beauveria, Metarhizium,
Paecilomyces, Aschersonia, Hirsutella, and Lecanicillium (formerly Verticillium) (Alves 1998b, Inglis et al. 2001, Goettel et al. 2005). Because the normal route of invasion is through the cuticle, fungi are especially suitable microbial control agents for sucking insects (Hemiptera).

Phylogenetic studies now confirm that the Microsporidia are highly derived organisms correctly placed among the lower fungi rather than extremely ancient and simple organisms classified with the Protozoa (Hirt et al. 1999). Although many microsporidians are common pathogens of arthropods, few have been included in microbial control programs because certain fundamental characteristics (complex life cycles, obligate parasitism, and chronic rather than acute effects) inhibit their use (Solter \& Becnel 2007).

Entomopathogenic nematodes (EPNs). Nematodes in the families Steinernematidae and Heterorhabditidae are effective control agents of dozens of insect species in soil and cryptic habitats (Kaya \& Gaugler 1993, Georgis et al. 2006, Shapiro-Ilan et al. 2005). These nematodes are associated with symbiotic bacteria (Xenorhabdus spp. and Photorhabdus spp.), which are housed in the intestine of the infective juvenile (IJ) nematode (also referred to as the Dauer stage). The IJ, the only free-living stage, occurs in the soil and searches for an insect host. Upon finding a host, it enters through the mouth, anus or spiracles and penetrates into the body cavity. In the case of heterorhabditids, IJ penetration can occur directly through soft cuticles. In the body cavity, the IJ releases mutualistic bacterial cells, which multiply rapidly and kill its insect host, usually within $48 \mathrm{~h}$. In addition, the bacterial cells digest host tissues and produce antibiotics that protect the host cadaver from saprophytes and scavengers, and allow the nematodes to develop and reproduce.

The nematodes feed on the mutualistic bacterial cells and on degraded host tissues. Depending on host size, there may be one to three nematode generations in the host cadaver. When host nutrients are depleted, the pre-IJs sequester the mutualistic bacterial cells in their intestines. The resulting IJs leave the host and search for new hosts. In the absence of a host, IJs can persist for months in moist soil. However, the IJs have their own natural enemies (i.e. nematophagous fungi, predatory mites and other soil predators) and must also contend with abiotic factors such as temperature extremes, low soil moisture, and ultraviolet radiation that affect their survival. Several EPN species are commercially produced and available for large-scale application. For small-scale experimental testing, EPNs can be produced in vivo and on artificial media (Kaya \& Stock 1997).

\section{Research and Application of Entomopathogens for Control of Arthropod Pests of Tropical Fruits}

The literature on microbial control agents of tropical fruit pests has, for the most part, concentrated on key pests of a few major crops (e.g. citrus and banana). In this review we bring information on the use of microbial control of arthropod pests of citrus, banana, coconut, mango, guava, papaya and pineapple. 


\section{Citrus}

Because of the diversity of cultivars and climates in which they are grown, citrus is perhaps the most widely distributed tree fruit crop ranging from tropical and subtropical climates to temperate habitats around the world. Consequently a huge range of arthropod pests is reported from citrus varieties (Smith $\&$ Peña 2002). Successful microbial control of several pests has been reported using fungi, bacteria, viruses and EPNs.

Citrus rust mite (CRM), Phyllocoptruta oleivora (Ashmead) (Acari: Eriophyidae). This is a major pest of citrus in several countries, including Brazil and the USA. Studies on the use of fungi for its control are limited number. Alves et al. (2005) assessed the pathogenicity of five concentrations of Beauveria bassiana (Bals.) Vuill. ranging from $10^{6}$ to $10^{8}$ condia/ml under laboratory conditions $\left(25^{\circ} \mathrm{C}\right.$, $12 \mathrm{~h}$ photophase, $98 \% \mathrm{RH})$. Mortality was time and dosage dependent and ranged from $24 \%$ to $91 \%$ with an $\mathrm{LC}_{50}$ of 4.23 x $10^{6}$ conidia/ml five days after treatment. $\mathrm{LT}_{50}$ at the highest concentration was 2.74 days. Hirsutella thompsonii Fisher (Entomophthorales: Moliniaceae) is infectious for CRM and several other mite pests of greenhouse crops, coconut and turf (Samson et al. 1980, McCoy 1996). In the early 1980's it was mass-produced and formulated by Abbott Laboratories (Chicago, IL, USA) and registered for CRM control in the USA (McCoy \& Couch 1982). Under optimal conditions, $H$. thompsonii can control CRM within one to two weeks (McCoy et al. 2007). Field applications of mycelia led to production of conidia within $48 \mathrm{~h}$ and provided suppression of CRM for up to 14 weeks (McCoy et al. 1971). McCoy et al. (2007) provided protocols for the field evaluation of $H$. thompsonii and other fungi intended for CRM control. Unfortunately, commercial development of the fungus was discontinued by Abbott Laboratories.

Citrus red mite, Panonychus citri (McGregor) (Acari: Tetranychidae). This mite can be a serious pest of citrus in certain locations. In southern China, Shi \& Feng (2006) evaluated the efficacy of four rates of B. bassiana (ranging from $1.2 \times 10^{12}$ to $3.0 \times 10^{13}$ conidia/ha) and a combination of the fungus with a low rate of pyridaben for control of $P$. citri in orange groves. All of the $B$. bassiana application rates produced significant mortality in $P$. citri and the combinations with pyridaben led to better control. Two applications of $>$ $1.5 \times 10^{13}$ conidia/ha plus low rate pyridaben with a 15 day spray interval resulted in good control of $P$. citri for 35 days with mite density declines of $74-91 \%$. Where $P$. citri is a pest in arid regions, it is not recommendable to use fungi against this pest. McCoy et al. (2007) summarized research and results of applications of a non-occluded virus found in $P$. citri. The virus has apparently been responsible for decimating epizootics in $P$. citri populations in Arizona and California (Reed 1981). Shaw et al. (1968) reported control of the mite after application of triturated mites infected with the virus. A major limitation of this virus is the need for its mass production in $P$. citri.

Broad mite (BM) or white mite, Polyphagotarsonemus latus
(Banks) (Acari: Tarsonemidae). This is a cosmopolitan pest of a variety of plants including citrus, papaya, and mango. It is abundant during warm and humid condition and thus an ideal candidate for control with fungi. However, very little research on microbial control has been conducted on this pest. Cabrera et al. (1987) reported natural infection of BM with H. thompsonii. Peña et al. (1996) assessed the infectivity of B. bassiana, H. thompsonii, and Paecilomyces fumosoroseus (Wize) Brown and Smith conidia in laboratory bioassays on bean leaves. The $\mathrm{LC}_{50}$ values for the fungi were $1.16 \times 10^{6}$, $2.39 \times 10^{3}$, and $1.29 \times 10^{5}$ conidia/ml, respectively. Mortality due to $B$. bassiana was most rapid in mite densities between 65 and 125 mites/leaf. The efficacy of $B$. bassiana and $P$. fumosoroseus and other agents were also evaluated against $\mathrm{BM}$ in a greenhouse test on potted bean plants. Treatments with $B$. bassiana were the most efficacious and persistent, and resulted in $88 \%$ mortality.

False spider mite (FSM), Brevipalpus phoenicis (Geijskes) (Acari: Tenuipalpidae). FSM, also known as the red and black flat mite, is a polyphagous widely distributed tropicalsubtropical species that has been reported from several hundred plant hosts including citrus, banana, macadamia, orchid, papaya, passion fruit, coffee and tea. FSM is an important citrus pest as it is a vector of the citrus leprosis virus (Childers et al. 2003). Rossi-Zalaf \& Alves (2006) assessed the activity of 52 isolates of fungi including $B$. bassiana, Metarhizium anisopliae (Metsch.) Sorokin, Paecilomyces spp., H. thompsonii, Lecanicillium spp. and others. The most active isolates were all $H$. thompsonii, causing 90-100\% mortality six days after treatment. All other species of fungi produced less than $30 \%$ mortality six days after treatment. The authors observed conidiogenesis of $H$. thompsonii with development of mycelium and condiophores emerging from the posterior and anterior parts of mites $120 \mathrm{~h}$ after spraying with conidia.

Whiteflies and blackflies (Hemiptera: Aleyrodidae). About 30 species of whiteflies and blackflies have been reported attacking citrus worldwide (Smith and Peña 2002), six of which are considered major pests. Fransen (1990), Lacey et al. (1996), and Faria and Wraight (2001) summarized the literature on fungi reported from whiteflies.

Most of research on microbial control of whiteflies in citrus has focused on Aschersonia spp., which has produced spectacular epizootics in conditions of high humidity and rainfall (Fig. 1a). In Florida, USA, Fawcett (1944) reported epizootics in Dialeurodes citri (Ashmead) and D. citrifolii (Morgan) in citrus groves during the summer when high humidity promoted conidial sporulation and host infection, and frequent rains enabled effective dispersal of the conidia. Meyerdirk et al. (1980) observed A. aleyrodis Ashby infecting D. citri in Texas. Elizondo \& Quezada (1990) published on the distribution of the citrus backfly, Aleurocanthus woglumi Ashby, and its natural enemies in four localities in Costa Rica. In addition to parasitoids and predators, mortality due to $A$. aleyrodis was significant. The same agent was unable to control $A$. woglumi following its introduction into and spread through El Salvador (Quezada 1974). Outbreaks of disease 

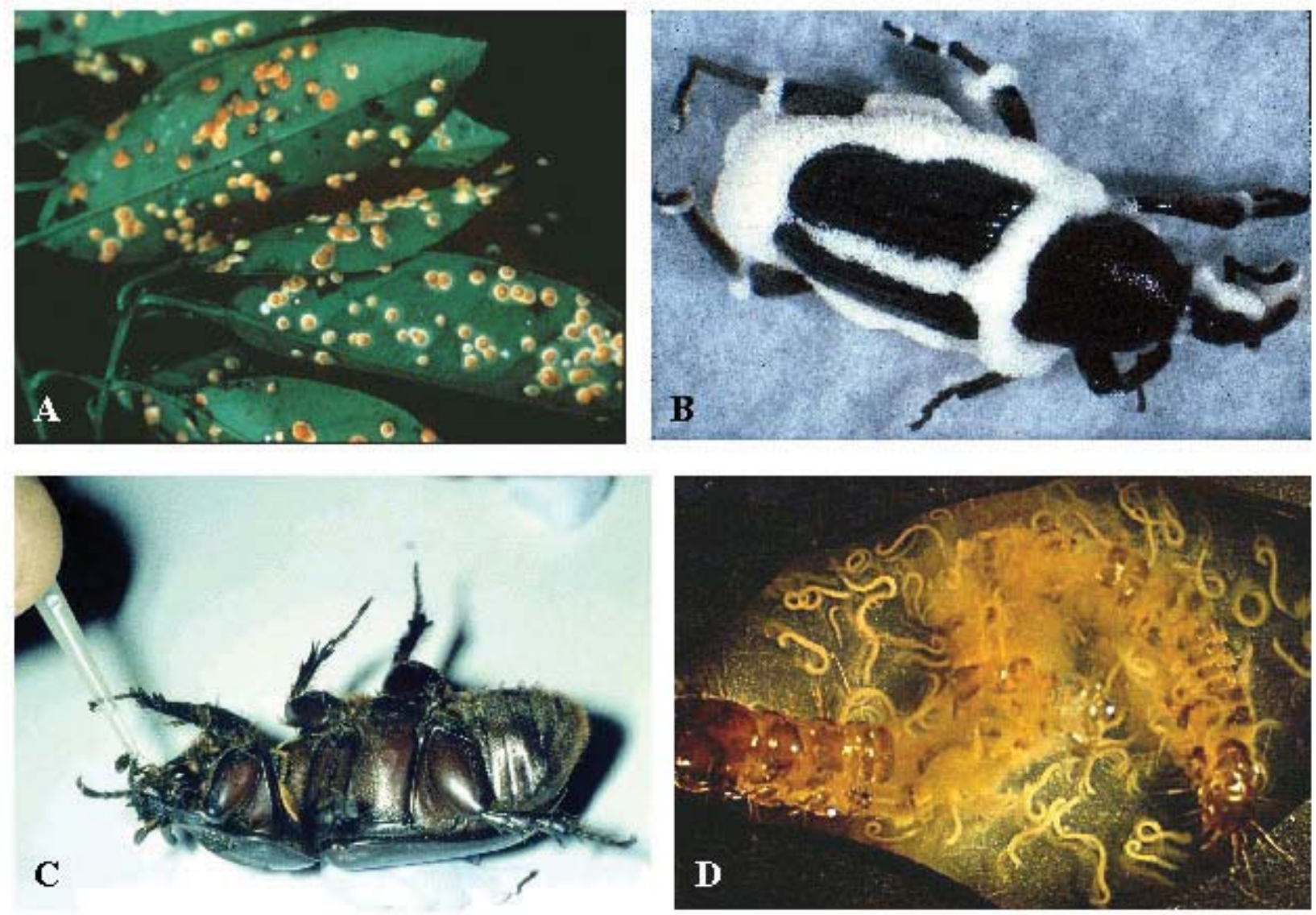

Fig. 1. A) Citrus whiteflies infected with Aschersonia aleyrodis. Photo coutesy of G. Xiong; B) Adult banana weevil infected with Beauveria bassiana. Photo courtesy of R. Duncan and J. Peña; C) Inoculation of palm rhinoceros beetle with Oryctes virus. Photo by C. Prior; D) Dissected banana moth larva showing various life stage of Steinernema carpocapsae. Photomicrograph courtesy of R. Duncan and J. Peña.

caused by Aschersonia spp. among populations of Bemisia giffardi (Kotinsky) on citrus in Taiwan were observed (Yen \& Tsai 1969).

In Brazil, the occurrence of Aschersonia spp. on whiteflies is very common in all areas where citrus is grown and coincides with the periods of greatest rainfall (Alves 1998b). In addition to natural occurrence, Aschersonia spp. has been successfully applied against whiteflies in citrus groves in the Georgia, China and Japan (Ponomarenko et al. 1975, Gao et al. 1985). In field tests in Japan Aschersonia sp. was pathogenic to nymphs, pupae and eggs of $D$. citri, and the mortality increased with the concentration of conidia (Uchida 1970). Ponomarenko et al. (1975) introduced several isolates of Aschersonia from six countries into orange groves near Adzharia, Georgia, being A. placenta Berk \& Br. from Vietnam and China the most effective leading to up to $90 \%$ parasitism in favorable weather.

Scales (Hemiptera: Coccidae and Diaspididae). These are regarded as the most abundant and injurious citrus pests (Smith \& Peña 2002). El-Choubassi et al. (2001) observed up to $49 \%$ infection of the diaspidid Parlatoria ziziphi (Lucas) by A. aleyrodis and $A$. goldiana Sacc. \& Ellis in Cuba. Gravena et al. (1988) noted that the main control agent of a diaspidid, Selenaspidus articulatus (Morgan), in a grove near São Paulo, Brazil, was A. aleyrodis. Yen \& Tsai (1969) observed fungal infections caused by Podonectria coccicola (Ellis \& Everhart) Petch, Pseudomicrocera henningsii (Koord.) Petch, and Sphaerostilbe aurantiicola (B. \& Br.) Petch in the coccids Chrysomphalus aonidum (L.), P. ziziphus and Lepidosaphes beckii (Newm.) in citrus groves in Taiwan. In South Africa, Moore (2002) reported several fungi attacking four scale pests of citrus. No publications on the applied use of fungi for control of scale in citrus were found in the literature.

Aphids (Hemiptera: Aphididae). Aphids, particularly those in the genus Toxoptera, are important pests of citrus, especially due to their roles as vectors of diseases such as citrus tristeza. Fungi are important natural enemies of aphids under warm and humid conditions (Latgé \& Papierok 1988, Humber 1997) but studies on their use in citrus groves have been limited. Poprawski et al. (1999) demonstrated good potential for control of the brown citrus aphid, Toxoptera citricida (Kirkaldy), with $B$. bassiana. Application of the fungus in field trials at $2.5 \times 10^{13}$ and $5.0 \times 10^{13}$ conidia/ha resulted in $79.8 \%$ and $94.4 \%$ control, respectively. 
Diaprepes root weevil, Diaprepes abbreviatus (L.) (Coleoptera: Curculionidae). This weevil is native to the Caribbean and has become a major pest in Florida citrus since its introduction was first reported in 1964 (Woodruff 1964). Annual losses and cost of control in Florida citrus are thought to exceed $\$ 72$ million (Peña et al. 2000).

Notching along the margins of young leaves is a typical sign of feeding by the adult. Eggs are laid on older leaves and, after hatching, larvae drop to the ground, enter the soil, and feed on roots for most of the year. Injury caused by the weevil appears to be cumulative; root damage impedes the plant to take up water and nutrients, and can result in tree mortality (Syvertsen \& McCoy 1985). In addition, this injury provides an avenue for fungal root rot infections by Phythophora spp. (Graham et al. 2003). A single larva can kill young trees, whereas several larvae can cause decline of older, established trees.

Since larvae are below ground, it is difficult to detect them before decline of above ground portions of the host plant is observed (Simpson et al. 1996). EPNs (Steinernematidae and Heterorhabditidae) are effective in soil habitats. Because D. abbreviatus larvae are vulnerable while entering the soil, numerous studies have been conducted on the use of EPNs for their control. In Florida, EPNs have been marketed for weevil control for over 15 years. Currently, two commercially available species, Steinernema riobrave Cabanillas, Poinar \& Raulston and Heterorhabditis indica Poinar, Karunakar \& David are used for control of the weevil. These nematodes appear to be most effective at high temperatures $\left(27 \pm 2^{\circ} \mathrm{C}\right)$ in coarse sandy soils. Larval mortality of over $90 \%$ has been reported for field trials with $S$. riobrave when applied at $1.2 \times 10^{10}$ infective juveniles (IJs)/ha (McCoy et al. 2002, 2007). Other EPN species, rates and percentage mortality were summarized by Shapiro-Ilan et al. (2002). The use of irrigation systems for application of EPNs has been effective in delivering IJs into the zone below trees where larvae enter the soil. Indigenous entomopathogenic fungi infect adults and larvae of $D$. abbreviatus and other weevils in the soil (McCoy et al. 2007).

Research conducted by Quintela \& McCoy (1998) demonstrated that a commercial oil formulation of $B$. bassiana (Mycotrol) or a combination of the fungus and a sublethal concentration of imidacloprid (a chloronicotinyl insecticide) provided effective control of neonate larvae and teneral adults when applied as a soil barrier. McCoy et al. (2007) pointed out that the efficacy of B. bassiana as a weevil control agent was limited by its poor persistence in soil. Weathersbee et al. (2002) demonstrated larvicidal and sublethal activity of elevated concentrations $B$. thuringiensis subsp. tenebrionis for D. abbreviatus in artificial diet and potted citrus tests.

Citrus root weevils, Pachnaeus spp. (Coleoptera: Curculionidae). Pachnaeus litus (Germar) and P. opalus (Oliver) are native to Florida and normally are considered minor pests, although they can damage young citrus plants (Tarrant \& McCoy 1989). The adults feed on tender foliage of citrus and eggs are laid on mature leaves, often on the same trees on which the adults have been feeding. Neonate larvae drop to the ground and quickly burrow into the soil where they feed on roots (Bullock et al. 1999). Field applications of $5 \times 10^{6} \mathrm{H}$. bacteriophora $\mathrm{IJ} / \mathrm{tree}$ resulted in significant reduction of $P$. opalus adults $(76 \%)$ as compared to controls (Downing et al. 1991). In another experiment, two applications of $S$. riobrave or $S$. carpocapsae at $2 \times 10^{6}$ IJs/tree provided an overall $64 \%$ and $53 \%$ reduction of $P$. litus, respectively (Bullock et al. 1999).

Fuller rose beetle (FRB), Asynonychus godmani Crotch (=Pantomorus cervinus (Boheman) (Coleoptera: Curculionidae). Adults feed on citrus foliage and cause leaf notching. Larvae develop for 6-10 months in the soil where they feed on the roots. The beetle does not usually cause economic damage but the presence of eggs on exported fruit requires fumigation. Morse \& Lindegren (1996) reported the results of field application of rather high rates of $S$. carpocapsae IJs against late-instar larvae under Valencia orange trees. A single application of the Kapow or All strain of $S$. carpocapsae, each applied at 50,150, and $500 \mathrm{IJs} / \mathrm{cm}^{2}$, reduced the number of emerging adult FRB a combined 55\% and $38 \%$, respectively, the year following treatment and $79 \%$ and $82 \%$, respectively, the 2 nd year. Based on EPN recovery six months after application and continued reduction of FRB emergence in the second year, the authors concluded that the EPNs persisted and recycled in the environment.

Citrus fruit borer, Ecdytolopha auratiana (Lima) (Lepidoptera: Tortricidae). In the late 1980's, E. auratiana became a key pest of citrus in São Paulo, Brazil. Females lay eggs on the fruit surface where neonate larvae enter the fruit and feed for approximately 20 days, rendering them worthless for consumption and processing. When fully grown, larvae leave the fruits and pupate in the soil. Laboratory tests with EPNs against sixth-instar larvae in pots containing sandy soil showed that $H$. indica applied at $1.6 \mathrm{IJ} / \mathrm{cm}^{2}$ resulted in $92 \%$ mortality (Leite et al. 2005).

False codling moth (FCM), Cryptophlebia leucotreta Merge (Lepidoptera: Tortricidae). This is an important pest of citrus in Africa and outlying islands (Moore 2002, Smith $\&$ Peña 2002). A granulovirus of FCM has shown promise in field trials. Fritsch (1988) conducted a small-scale field trial of the virus formulated with skimmed milk powder and a wetting agent and applied at $10^{8}$ and $10^{9}$ granules $/ \mathrm{ml}$ on FCM-infested citrus in Cape Verde, resulting in a $77 \%$ reduction of FCM population. Moore (2002) provided a synopsis of research conducted on this virus in South Africa and concluded that it plays a natural regulatory role in FCM populations. Application of the granulovirus at rates of $10^{14}$ to $10^{15} \mathrm{OBs} /$ ha provided up to $60 \%$ reduction of FCM infestations in navel oranges. Subsequently, 17 field trials have been conducted on citrus in three different provinces in South Africa. Where spray coverage was thorough and FCM pressure was moderate, infestation was reduced by $70 \%$ following a virus treatment three weeks before harvest (Moore et al. 2005). The virus has been registered for use and is now commercially produced in South Africa.

Old world bollworm, Helicoverpa armigera (Hübner) 
(Lepidoptera: Noctuidae). This insect attacks a wide variety of important crops in portions of Africa, Asia, Australia, and Europe. In South Africa and parts of Asia, it is a serious pest of citrus. B. thuringiensis subsp. kurstaki (Btk) has been applied for control of $H$. armigera in citrus, but growers have reported dissatisfaction with its efficacy (Moore et al. 2004). Field trials of the nucleopolyhedrovirus of $H$. armigera conducted by Moore et al. (2004) demonstrated that it was superior to Btk for suppression of the bollworm. Application of $7.26 \times 10^{5}$ and $1.15 \times 10^{6} \mathrm{OBs} / \mathrm{ml}$ resulted in $100 \%$ reduction in bollworms within 14 days of application. Damage to fruit was reduced by up to $75-84 \%$ and rejection for export was reduced by $62-96 \%$.

Other lepidopteran pests. The citrus leafminer, Phyllocnistis citrella Stainton (Phyllocnistidae) is a significant pest of citrus worldwide. Field application of Bt against the leafminer in the Azores resulted in significant larval mortality $48 \mathrm{~h}$ after treatment (Dias et al. 2005). Shapiro et al. (1998) observed that leaf damage and number of $P$. citrella larvae were significantly reduced after 21 days by treatments of Bt plus a wetting agent. Beattie et al. (1995) demonstrated only limited potential for control of $P$. citrella with $S$. carpocapsae. Narayanamma \& Savithri (2003) and Gopalakrishnan \& Gangavisalakshy (2005) reported successful control of the citrus butterfly, Papilio demoleus L. (Papillionidae), on sweet orange following applications of $B t$ at two locations in India. The citrus leafroller, Cacoecia occidentalis Walsingham (Tortricidae) is a minor pest of South African citrus. Smith et al. (1990) described a granulovirus with potential for its control.

Fruit flies (Diptera: Tephritidae). Some species, such as the Mediterranean fruit fly, Ceratitis capitata Weidemann, are key or major pests of citrus in tropical production areas. Several authors have reported the results of research for control of $C$. capitata and other tephritid species using EPNs and fungi in laboratory studies and field trials in other agroecosystems (see mango section).

\section{Banana}

Several varieties of banana and plantain (Musa spp.) are grown throughout the tropics and into the sub-tropics. In addition to providing indigenous populations with rich sources of carbohydrate and other nutrients, banana and plantain are valuable export crops. A wide variety of insects and mites attack banana and include species that bore into the trunk, pseudostem, rhizomes, corm and roots, and species that attack flowers, fruits and foliage (Gold et al. 2002).

Banana weevil (BW), Cosmopolites sordidus (Germar) (Coleoptera: Curculionidae). This weevil is reported as the most important insect pest of banana and plantain (Gold et al. 2001). Oviposition takes place at the base of the plant and neonate larvae bore into the corm. Heavy infestations can result in crop failure in newly established stands and reduced yield and shortened life span of plants in established stands (Gold et al. 2001, 2002).
Strains of $B$. bassiana have shown good potential to control adult BW (reviewed by Gold et al. 2002, 2003) (Fig. $1 \mathrm{~b})$. Mortality in adult weevils of up to $60 \%$ was reported. Godonou et al. (2000) evaluated two formulations of $B$. bassiana (oil palm kernel cake-based formulation of conidia [OPKC] and conidial powder) applied to the planting holes and suckers of banana. Both formulations resulted in $75 \%$ mortality in artificially released weevils. Under natural infestation conditions, the OPKC performed better $(42 \%$ mortality) than the conidial powder (6\%). Bautista Filho et al. (1995, cited by Alves 1998 b) reported up to $61 \%$ reduction of BW adults after treatment with $B$. bassiana.

A major constraint to the use of $B$. bassiana is the lack of an economic means of effectively applying the fungus. In Brazil, baits were made of sections of banana pseudostem treated in a suspension of $B$. bassiana conidia, mycelia and medium or with a paste that resulted in application of $5 \mathrm{x}$ $10^{9}$ conidia/bait. Fifty baits/ha were recommended being baits replaced 15 days, until less than $5 \mathrm{BW}$ are captured/ bait. Tinzaara et al. (2004) improved targeted delivery of the fungus in and near traps baited with an aggregation pheromone that is attractive to both sexes. B. bassiana is transmitted horizontally among BW individuals (Schoeman \& Schoeman 1999, Godonou et al. 2000, Tinzaara et al. 2004), and this greatly improves the dissemination of the fungus within populations. Also, as most mycosed adult cadavers are found in the leaf sheath at the base of plants, the likelihood that ovipositing females and mating pairs to come into contact with recently produced conidia is increased (Tinzaara et al. 2004).

Gold et al. (2003) reviewed the research of several authors on the potential of endophytic fungi (Fusarium spp., Acremonium spp., Geotrichum spp.) for BW suppression. The most effective species in this role was Fusarium oxysporum Schltdl.

Laboratory, greenhouse and field assays demonstrated the activity of EPNs against BW. Rosales \& Suarez (1998) evaluated exotic and native EPNs in Venezuela and found some native isolates of Heterorhabditis with good potential for BW control. Figueroa (1990) evaluated S. carpocapsae, $S$. glaseri (Steiner) and $S$. feltiae (Filipjev) against BW in greenhouse tests in Puerto Rico. The nematodes significantly reduced the number of tunnels made by larvae in plantain corms at 400, 4,000 and 40,000 IJs/four-month-old plant. At the two higher rates, $100 \%$ larval mortality was achieved.

Treverrow \& Bedding (1993) assayed 32 strains and species of Steinernema and Heterorhabditis against larvae and adults of BW and reported the greatest activity of the BW strain of $S$. carpocapsae against adults. They also described a method for introducing $S$. carpocapsae IJs into banana corms that involves removing cones ( $50 \mathrm{~mm}$ diam. by $150 \mathrm{~mm}$ long) from residual corms with a desuckering gouge and adding $2.5 \times 10^{5} \mathrm{IJs} /$ cavity. The cone is then reinserted to produce a protected cavity that is attractive to adult weevils. Treverrow et al. (1991) also reported significant mortality (43-68\%) of BW larvae in banana rhizomes after applying $S$. carpocapsae with a water thickener into cuts or holes made in residual rhizomes. Mortality of adult BW attracted to the application sites on treated rhizomes was also observed. In contrast, bi- 
monthly treatments with Heterorhabditis zealandica Poinar and $S$. carpocapsae applied in a thickened aqueous solution into $200 \mathrm{~mm}$ deep incisions in the residual rhizomes of harvested plants from November to May failed to produce adequate control (Smith 1995). The author speculated that the treatments were not effective possibly because of early nematode mortality caused by free water in the spike holes and/or because of the need for more frequent applications. Kermarrec \& Mauleon (1989) demonstrated synergy between the insecticide chlordecone and S. carpocapsae for control of BW. Other studies on EPNs for BW control were summarized by Gold et al. (2002).

West Indian sugarcane borer, Metamasius hemipterus sericeus (Olivier) (Coleoptera: Curculionidae). This pest is also known as the silky cane weevil and rotten stalk borer of sugar cane. It can be an important pest of banana in certain areas of the Americas (Giblin-Davis et al. 1994, Gold et al. 2002). As with BW, fungi and nematodes have potential to control this pest. Peña et al. (1995) reported infection of low density populations of the insect by $B$. bassiana in a threeyear old banana field in Florida. They observed up to $70 \%$ infection when more than ten weevils were captured/trap. Unlike BW, M. hemipterus sericeusis are strong fliers and could disperse fungi from sources of inoculum (i.e. through attractant traps) into neighboring populations. Giblin-Davis et al. (1996) evaluated $S$. carpocapsae in palm for control of this pest (see coconut section).

Banana moth, Opogona sacchari (Bojer) (Lepidoptera: Tineidae). This insect is only a minor pest of banana, but a serious pest of certain types of palms. Research on EPNs for its control are reported by Peña et al. (1990) in the coconut section.

Opsiphanes tamarindi Felder (Lepidoptera: Brassolidae). This is a major defoliator of plantains during the dry season in the region south of Lake Maracaibo, Venezuela. Broad-spectrum insecticides have been ineffective for its control. Briceno (1997) described an IPM system that combined cultural practices, application of Bt against early larval stages, and relying on natural enemies (parasitoids and predators) to control late larval and pupal stages. The seasonal application of Bt helped to eliminate first instars without affecting natural enemies.

Bagworm, Oiketicus kirbyi Guilding (Lepidoptera: Psychidae). This is a defoliating pest of banana in Costa Rica and Colombia (Gold et al. 2002). Stephens (1962) noted the occurrence of $B$. bassiana and a Nosema species in bagworm larvae in Costa Rican bananas.

\section{Coconut}

Coconut is significant and sometimes predominant sources of income for several tropical countries. Although a multitude of insects and mites exert varying degrees of economic impact on it, microbial control agents have been used on relatively few of them.
Palm rhinoceros beetles, Oryctes spp. (Coleoptera: Scarabaeidae: Dynastinae). These beetles are serious pests of coconut throughout the old world tropics. Oryctes rhinoceros (L.) is one of the most important pests of coconut in Southeast Asia and several South Pacific islands (Bedford 1980). Adults attack the heart of plants and feeding can reduce yield and kill trees (Bedford 1980, Zelazny 1983). Larvae develop mainly in rotting palm trunks.

One of the most successful uses of an entomopathogen for classical biological control is reported for $O$. rhinoceros. In 1966 , Huger described a non-occluded virus of $O$. rhinoceros from Malaysia that demonstrated potential for long-term control (Huger 1966, 2005). Adults become chronically infected via oral contact with the virus and subsequently serve as reservoirs and disseminators (Huger 1973, Zelazny 1973, Bedford 1981). The midgut epithelial cells of adults become heavily infected (Huger 1973); individual beetles may produce and excrete up to $0.3 \mathrm{mg}$ of virus per day (Monsarrat \& Veyrunnes 1976). Viral transmission among adults occurs during mating, when they feed in palms contaminated with feces containing the virus, or in larval breeding sites (Zelazny 1976, Young \& Longworth 1981, Zelazny \& Alfiler 1991). There are no external symptoms of the disease in adults and it is not immediately fatal (Zelazny 1973). However, it shortens lifespan and reduces fecundity of infected adults. Infected beetles stop feeding, fly less frequently, and the males mate less often (Zelazny 1977). Transmission to larvae occurs when virus-infected adults defecate in breeding sites (Zelazny 1972, 1976). Viral infection in larvae is always lethal. Studies with other Oryctes species and Strategus aloeus (L.) revealed that the virus is cross-infective to certain other Dynastinae (Lomer 1987). Control of O. monoceros (Olivier), a serious coconut pest in Africa, with the Oryctes virus was reported by Lomer (1986) and Purrini (1989).

The preferred method for disseminating the virus in coconut plantations has been the infection and release of $O$. rhinoceros adults (Fig. 1C), which resulted in establishment of the virus within larval and adult habitats in several locations in Asia, Africa, and the South Pacific (Bedford, 1981; Zelazny, 1978; Young \& Longworth 1981; Jones et al. 1998; Huger 2005) where it was previously absent. As few as ten infected beetles can successfully establish the virus on an island (Jones et al. 1998). Introduction of virus into artificial and natural larval habitats has also been used successfully to inoculate beetle populations (Bedford 1980). Since 1967, the introduction of virus into coconut plantations in several South Pacific islands and other locations has resulted in significant control of $O$. rhinoceros. Integrated measures that include removal or covering of old palm logs that serve as breeding sites along with inoculative releases of the virus have reduced the density of Oryctes populations to below economic thresholds in many locations (Bedford 1980, Zelazny et al., 1992; Alfiler 1992).

Despite the successes of introducing the virus into previously virus-free islands, $O$. rhinoceros remains a serious threat in the coconut and oil palm plantations of Southeast Asia and the Pacific. The prohibition of burning palm logs in the 1990's as a method for maintaining plantation hygiene has dramatically aggravated the problem (Jackson et al. 2005, 
Ramle et al. 2005). In such situations, $O$. rhinoceros outbreaks are not caused by the absence of the virus disease, but by ecological disturbances in the transmission cycle of the virus, like the availability of large number of coconut palms for insect breeding. Under these conditions there is little contact between virus-infected and healthy individuals, whereas a low density of dead-standing palms creates good conditions for spread of the virus (Zelazny \& Alfiler 1986, Alfiler 1992, Zelazny et al. 1992). Ecological methods for promoting the spread of the virus are to: 1) hide trunks of felled palms from the beetles by promoting the growth of cover crops over them, rather than attempting to burn the trunks, and 2) leave about five deadstanding coconut palms/ha (Zelazny \& Moezir 1989).

DNA analysis in Malaysia revealed several distinct viral genotypes with different virulences. The most virulent for larvae and adults (type B) was produced in vivo and released into healthy populations. Examination of beetles from the release site and vicinity demonstrated the spread and persistence of type B with concomitant reduction in palm damage (Ramle et al. 2005). Decreased control has been reported from other earlier release sites. Jackson et al. (2005) reported considerable genetic variation in the virus that suggests its rapid evolution. They recommended a renewed coordinated effort for the selection and distribution of virulent viral strains. Earlier work by Zelazny et al. (1990) showed some distinct differences in virulence among strains of the Oryctes virus. Marschall and Ioane (1982) demonstrated that re-release of the virus could result in an increase of the infection rate with a reduction of palm damage.

The combined use of the fungus $M$. anisopliae in larval breeding sites and release of virus has also been proposed (Young 1974, Marschall \& Ione 1982), but the fungus does not spread well between breeding sites (Zelazny \& Alfiler 1986). The Oryctes virus has remained the most important biological control agent, however $O$. rhinoceros populations in Java and the southern parts of Sulawesi, Indonesia, are suspected of having developed resistance to the virus (Zelazny et al. 1989).

Root weevils (Coleoptera: Curculionidae). The rotten sugar cane borer and the Diaprepes root weevil are reported as pests of several palm species (Weissling \& Giblin-Davis 1998). Research on the use of EPNs and fungi for control of these pests has been conducted in banana and citrus, respectively. Experiments with $S$. carpocapsae applied at $8 \times 10^{6} \mathrm{IJs} /$ palm conducted by Giblin-Davis et al. (1996) on M. hemipterus sericeus-infested Canary Island date palms (Phoenix canariensis Hort. ex Chabaud) resulted in 51\% mortality in weevil larvae. Because of high weevil production/palm, Giblin-Davis et al. (1996) recommended that EPNs should be applied frequently and over a long period of time for effective management. The precise interval of application and duration of treatments will depend on environmental conditions and population density of the weevil (J. Peña, personal communication).

\section{Mango}

Over 260 species of insects and mites have been recorded as pests of mango worldwide (Peña et al. 1998, Waite 2002).
Key pests that require regular control measures include fruit flies, seed weevils, tree borers and various Hemiptera.

Fruit flies (Diptera: Tephritidae). Fruit flies are among the most serious pests of tropical fruit and are regarded as the principal pests of mango. Anastrepha ludens (Loew) develops in a variety of fruit crops, but is especially damaging in mango and citrus. It is widely distributed in Mexico, most of Central America and southern United States. The Caribbean fruit fly, Anastrepha suspensa Loew, is a pest of mango and several other tropical fruits and is distributed within the Greater Antilles, Bahamas and Florida. Anastrepha obliqua (Maquart) is a significant pest of mango in Brazil and most of the new world tropics, but it has not yet been tested for susceptibility to entomopathogens. C. capitata and other Ceratitis spp. have been reported from mango and many other fruit worldwide. The oriental fruit fly, Bactrocera dorsalis (Hendel), is a pest of a wide range of fruit in Asia and is a key pest of mango in India. Fruit fly females oviposit in ripening fruit, and larvae burrow into the pulp. Fully grown larvae exit the fruit, usually after it has fallen to the ground, and pupate in the soil.

EPNs and fungi have been evaluated as alternatives to conventional insecticides for control of some important fruit fly pests of mango. Although A. ludens is susceptible to a variety of EPN species under laboratory conditions (LezamaGutiérrez et al. 1996, Toledo et al. 2001, 2005), extremely high rates are required for control in the field $\left(2.5 \times 10^{2} \mathrm{IJS}\right.$ of $H$. bacteriophora $/ \mathrm{cm}^{2}$ ) (Toledo et al. 2006). Similarly, laboratory and field research conducted on the effectiveness of EPNs against $C$. capitata, revealed susceptibility of larvae to several nematode species (Lindegren \& Vail 1986, Gazit et al. 2000, Laborda et al. 2003), but high application rates are required for control in the field (5 to $50 \times 10^{2} \mathrm{IJs}$ of $S$. carpocapsae $/ \mathrm{cm}^{2}$ (Lindegren et al. 1990). Research on the susceptibility of other fruit flies of mango has been limited to the laboratory. Lindegren \& Vail (1986) reported on the susceptibility of $B$. dorsalis to $S$. carpocapsae and Beavers \& Calkins (1984) reported on the evaluation of A. suspensa susceptibility to several steinernematids and heterorhabditids.

Testing of fungi on fruit flies of mango has been predominantly on M. anisopliae and B. bassiana. Laboratory and field research by Ekesi et al. $(2002,2003,2005)$ and Dimbi et al. (2003a, 2003b) on M. anisopliae against Ceratitis spp. elucidated the effect of various factors on the activity of the fungus that included temperature, moisture, gender, life stage and fly species. Mochi et al. (2006) investigated the effect of fungicides, acaricides, insecticides and herbicides on $M$. anisopliae activity against $C$. capitata in laboratory exposures in field-collected soil. Significant pupal and adult mortality occurred in soil treated with the fungus with and without pesticides. No larval mortality was observed. Pesticides affected fungal activity slightly with the most significant effect due to the fungicides chlorothalonyl and tebuconazole.

Laboratory and field studies on $M$. anisopliae activity against $A$. ludens were reported by Lezama-Gutiérrez et al. (2000). When M. anisopliae was applied in field cages at 
$2 \times 10^{5}$ conidia $/ \mathrm{cm}^{2}$, adult emergence was reduced by up to $43 \%$ in loam soil. Castillo et al. (2000) studied the activity of strains of $M$. anisopliae and $P$. fumosoroseus against $C$. capitata adults and reported $\mathrm{LD}_{50}$ values of $5.1 \times 10^{3}$ and 6.1 x $10^{3}$ conidia/fly, respectively, for the two most active strains. They also noted a sublethal effect of the fungi on fecundity. Konstantopoulou and Mazomenos (2005) reported on the laboratory evaluation of $B$. bassiana and $B$. brongniartii against adults of $C$. capitata and Rosa et al. (2002) studied the effects of $B$. bassiana on $A$. ludens. In both studies, adult flies were very susceptible to infection by conidia, but Rosa $e t$ al. (2002) reported negligible effects on larvae and pupae.

Mango seed weevil, Sternochetus mangiferae (F.) (Coleoptera: Curculionidae). This is a widespread pest of mango. Eggs are usually laid on green fruit and larvae tunnel to the seed where they develop. Joubert \& Labuschagne (1995) reported laboratory and field tests with two strains of B. bassiana, but neither strain had an effect on $S$. mangiferae. Shukla et al. (1984) described the isolation of a virus infecting larvae of $S$. mangiferae in India. It caused reduction in feeding, sluggishness, browning of the integument and milkiness of the haemolymph. The authors discussed the similarity of the virus to that reported in O. rhinoceros.

Rhytidodera bowringii White (Coleoptera: Cerambicidae). Zhou et al. (1998) reported on the evaluation of B. bassiana against Rhytidodera bowringii White. The fungus was isolated from dead $R$. bowringii adults and subsequently used to produce inoculum for field experiments in China. Treatment of two older mango orchards with $B$. bassiana resulted in $84 \%$ mortality of the beetle.

Mango mealy bug, Drosicha mangiferae Green (Hemiptera: Margarodidae). Srivastava \& Fasih (1988) found $B$. bassiana infecting nymphs of $D$. mangiferae in mango orchards in five localities in Lucknow, India. In field trials on infested mango panicles, spray application of a suspension of $4.8 \times 10^{6} \mathrm{conidia} / \mathrm{ml}$ reduced populations of $D$. mangiferae by $33-100 \%$ in ten days. Masarrat \& Srivastava (1998) demonstrated the dose-mortality relationship of $B$. bassiana against $D$. mangiferae first-instar nymphs in laboratory assays. Mohan et al. (2004) showed insecticidal activity for Photorhabdus luminescens (Akhurst) (the symbiotic bacterium isolated from $H$. indica). Application of a formulation of $1.4 \times 10^{6}$ cells $/ \mathrm{ml}$ of $P$. luminescens on $D$. mangiferae-infested mango twigs resulted in $92.5 \%$ mortality of second-instar nymphs after $48 \mathrm{~h}$.

Mangohopper, Amritodus atkinsoni Lethierry (Hemiptera: Cicadellidae). Vyas et al. (1993) reported that a $75 \mathrm{~min}$ exposure to $10^{9} \mathrm{M}$. anisopliae conidia/g of inert dust caused $100 \%$ mortality of $A$. atkinsoni after $96 \mathrm{~h}$. Concentrated aqueous suspensions of the fungus $\left(10^{9}\right.$ conidia $\left./ \mathrm{ml}\right)$ were considerably less effective. Srivastava \& Tandon (1986) reported natural infection by the fungi Lecanicillium lecanii (Zimm.) and B. bassiana in populations of the leafhopper Idioscopus clypealis (Lethierry) on mangoes in Uttar Pradesh, India.

\section{Guava}

Psidium guajava L. is native to the American tropics but is currently grown in more than 50 subtropical and tropical countries. Brazil is the principal red guava producer followed by Mexico whereas India is the major producer of white guava (Gould \& Raga 2002). Different pests attack fruits, leaves and trunk, causing more or less damage depending on the region or country. Main pests of fruits are the guava weevil (Conotrachelus psidii Marshall) and fruit flies ( $C$. capitata and Anastrepha spp.). On the leaves, the main pest is a psyllid (Triozoida sp.) that causes damage mainly after pruning when new leaves start growing (Souza et al. 2003).

Fruit flies (Diptera: Tephritidae). Fruit flies are very important pests in guava because the adults lay eggs in the fruit, and resulting damage by larvae lowers its quality. In Brazil, the main species in guava are Anastrepha fraterculus (Wied.), A. obliqua, A. sororcula (Zucchi), A. zenildae (Zucchi) and C. capitata (Souza et al. 2003). Most of the research on microbial control of these pests has been conducted in other tropical fruit crops, most notably in mango (see mango section).

Guava weevil, Conotrachelus psidii Marshall (Coleopera: Curculionidae). This is a major pest of guava in certain areas in Brazil. Females lay eggs in immature fruit $(3-4 \mathrm{~cm}$ diameter) and larvae progress through four instars as the fruit develops. Infestation leads to acceleration in fruit maturation and fruit drop when ripe. At this moment, larvae crawl into the soil where they develop into prepupae. Individuals may remain in this stage for up to six months before pupation and development into the adult (Boscán de Martinez \& Cásares 1982, Bailez et al. 2003). Control methods involve weekly applications of insecticides to suppress adults, but most of those currently in use for guava weevil control will be discontinued soon (Souza et al. 2003, Agência Nacional de Vigilância Sanitária 2004). Without chemical control, the percentage of damaged fruit in heavily infested orchards can reach 100\% (Bóscan de Martinez \& Cásares 1980). The amount of fruit attacked has been increasing over the past three years possibly due to the development of insecticide resistance (reference?). Poorly timed chemical applications and the tendency for adult weevils to hide in the litter around trees and avoid contact with the chemicals could also be involved (Denholm \& Rolland 1992).

The virulence of four species/strains of EPNs to fourthinstar larvae was assessed in the laboratory. In petri dish assays with sterile sand at $100 \mathrm{IJ}$ /larva, larval mortality ranged from $33.5 \%$ to $84.5 \%$, with the heterorhabditids being the most virulent. In sand column assays with $H$. baujardi LPP7, H. indica Hom1, and S. riobrave 355 at 100, 200 and $500 \mathrm{IJ}$ /larva, significant mortality was observed only for $H$. baujardi $(62.7 \%)$ and $H$. indica $(68.3 \%)$ at the highest dose. For $H$. baujardi LPP7, the $\mathrm{LT}_{50}$ and $\mathrm{LT}_{90}$ for $100 \mathrm{IJS}_{\mathrm{S}}$ were 6.3 and 9.9 days, whereas the $\mathrm{LC}_{50}$ and $\mathrm{LC}_{90}$ over seven days were 52 and 122.2 IJs (Dolinski et al. 2006). In a greenhouse study with guava trees in 20 -L pots (ten weevil larvae/pot), 
and doses of 500,1000 or $2000 \mathrm{IJs} /$ pot, H. baujardi LPP7 caused $30 \%$ and $58 \%$ mortality at the two highest doses (Dolinski et al. 2006).

In small farms in Cachoeiras de Macacu, RJ, Brazil, a combination of different control methods against the guava weevil is being implemented. $H$. baujardi LPP7 is applied in orchards as infected cadavers. Initial results indicate a $40 \%$ to $70 \%$ decrease in adult weevils by applying 20 cadavers/tree. In addition, removal of all damaged fruit from their orchards helps to reduce pest population in the following year. Another alternative is the weekly application of neem oil against adults and neem cake applied to the soil for control of larvae. By eliminating pesticides, these strategies have effectively reduced production costs by $40 \%$. Recently, fruit quality and yield are being assessed (Dolinski 2006).

Leaf-footed bug, Leptoglossus zonatus Dallas (Hemiptera: Coreidae). This is usually a secondary pest on fruits and flowers. Few attempts to control this pest with microbials were published. Three B. bassiana isolates and one isolate of M. anisopliae were assessed in the laboratory against adults (Grim \& Guharay 1998), being M. anisopliae NB the most efficient. In a field trial, mineral oil-based ultra low volume controlled droplet applications of $M$. anisopliae NB at $10^{10}$ conidia/tree caused $94 \%$ adult mortality. When $B$. bassiana was applied, there was a $28 \%$ increase in fruit yield.

\section{Papaya}

Carica papaya L. originated in southern Mexico, Central America and northern South America and is cultivated in most tropical countries (Morton 1987a). A total of 134 species of arthropods are reported to attack papaya, some of which are important vectors of major pathogens of papaya (Pantoja et al. 2002). Since most fruit production is for exportation and the presence of pesticide residues is not tolerated, the use of alternatives to chemicals, including cultural methods and microbial control, are being increasingly employed.

Fruit flies (Diptera: Tephritidae). Fruit flies comprise the most important pests of papaya in most producing regions. Research on the use of microbial control agents (EPNs and fungi) against several species that attack papaya (Anastrepha spp., Ceratitis spp., B. dorsalis) has been conducted in other tropical fruit crops, most notably in mango (see mango section).

Twospotted spider mite, Tetranychus urticae Koch (Acari: Tetranychidae). This is the most important pest in papaya in Brazil, and is responsible for a major portion of the production costs (Alves et al. 2002). Because of the high temperatures and humidity in areas where papaya is grown, fungi have potential as microbial control agents of mites. Alves et al. (2002) reported use of B. bassiana on over 1000 ha of commercial papaya production in Brazil for control of T. urticae.

Most of the research on B. bassiana and T. urticae has been conducted in other crops. Laboratory tests with $B$. bassiana against eggs, deutonymphs, protonynphs, larvae and adult stages of T. urticae on green bean showed positive results (Saenz-de-Cabezon et al. 2003). The $\mathrm{LC}_{50}$ for juvenile stages and adults was 3184 and 1949 conidia/ml, respectively. No significant differences in mortality were observed among egg age classes (24-96h-old eggs) at the tested concentrations (1400-22,800 viable conidia/ml).

Natural epizootics of fungi in the genus Neozygites have been responsible for spectacular declines in $T$. urticae populations in other cropping systems (reviewed in Steinkraus 2007).

Broad mite, P. latus. This is also a significant pest of papaya in some areas (Pantoja et al. 2002). Peña et al. (1996) investigated the use of $B$. bassiana and other fungi against this pest (see citrus section).

Aphids (Hemiptera: Aphididae). Although aphids do not colonize papaya, they are considered important potential vectors of papaya diseases (Pantoja et al. 2002). Many fungi (several Entomophthorales and L. lecanii) have resulted in massive natural epizootics in other cropping systems in some of the same aphids that attack papaya (e.g., Aphis gossypii Glover, Myzus persicae (Sulz.) (Latgé \& Papierok 1988, McCoy et al. 1988, Steinkraus 2007). Their potential to control aphids and other hemipteran papaya pests warrants further attention.

Other hemipteran pests. Papaya scale, Philephedra tuberculosa Nakahara and Gill (Hemiptera: Coccidae) attacks papaya and annona fruits. It is naturally infected by the fungus $L$. lecanii, which can lead to $90 \%$ mortality during summer (Peña et al. 1987, Peña \& Johnson 2006). A variety of mealybugs, whiteflies, and leafhoppers attack papaya (Pantoja et al. 2002). Although literature on microbial control of these pests on papaya is scant, several fungi are reported to attack these insects in other agroecosystems, including tropical fruit (McCoy et al. 1988, Fransen 1990, Lacey et al. 1996, Goettel et al. 2005). Research on the use of fungi for control of these species in papaya is warranted.

\section{Pineapple}

Ananas comosus (L.) Merril is native to Brazil, Bolivia, Peru, and Paraguay, and is currently cultivated in most tropical countries (Morton 1987b). It is the third largest fruit crop (after bananas and mango) harvested in the tropics (Petty et al. 2002). These authors provided a summary of arthropod pests of pineapple worldwide and considered pink pineapple mealybug, Dysmicoccus brevipes (Cockerell) as the key pest worldwide.

Mealy bugs, Dysmicoccus brevipes and D. neobrevipes (Hemiptera: Pseudococcidae). Mealy bugs cause wilting due to the toxic effect of their feeding. There is potential for using EPNs against this pest based on work done with a closely related species, D. vaccinii Miller \& Polavarapu (Stuart et al. 1997). 
Large moth, Thecla basalides (Lepidoptera: Lycaenidae). This insect is an important pest of pineapple in Brazil, mainly in the cultivar 'Pérola'. Females lay eggs from the beginning of flowering until fruit formation. Larvae penetrate the flowers and complete development in 13 to 16 days (Fazolin 2001). In Northern Brazil, the dose of $600 \mathrm{~g} / \mathrm{ha}$ of Bt is recommended for control (Sanches 2005). In Southern Brazil, Lorenzato et al. (1997) reported on the natural enemies of $T$. basalides and effectiveness of insecticides. Application of $\mathrm{Bt}$ resulted in effective control.

White grubs (Coleoptera: Scarabaeidae). The larval stages of 23 species of scarabs in three sub-families were reported to attack the subterranean organs of pineapple plants in several locations worldwide, with the most serious pests reported from Australia and South Africa (Petty et al. 2002). Although no specific studies on the use of microbial control agents have been reported for white grubs in pineapple, pathogens have been successfully applied for their control in other crops (Jackson \& Glare 1992, Klein et al. 2007). Candidate control agents include fungi [M. anisopliae, Beauveria brongniartii (Sacc.) Petch], bacteria (Bt, Paenibacillus spp., Serratia entomophila Bizio), and EPNs (Heterorhabditis spp., Steinernema spp.)

\section{The Role of Microbial Control in Integrated Pest Management (IPM) in Tropical Fruits}

Integrated Pest Management plays a significant role in crop protection being an important aspect of sustainable agriculture that attempts to minimize the negative environmental impacts and other deleterious effects due to the use of chemicals (Huffaker 1985, Dent 2000). Individual components of IPM are often evaluated as stand-alone tactics without consideration of their interactions with other components of the agroecosystem.

An integrated approach that is based on pest densities and their relation to economic injury thresholds will ultimately be required for each cropping system and location before agriculture will be truly sustainable. When selective insecticides are used, the negative impact on beneficial insects is reduced. Biopesticides provide an alternative means of control that further minimizes impacts on beneficials and other non-target organisms (NTOs). This is due to the specific nature of many microbial control agents. Safety testing data for entomopathogens indicate that they are generally safe for most NTOs, especially vertebrates (Laird et al. 1990, Akhurst \& Smith 2002, Hokkanen \& Hajek 2003). However, it will be necessary to determine their effects on the beneficial organisms under the specific conditions in each agroecosystem.

The way in which entomopathogens are utilized, i.e. augmentation, inoculative introduction (classical biological control) or conservation, will depend on the characteristics of the pest and the fruit crop in which it causes damage or yield loss. Fruit crops are stable agroecosystems where any of the above strategies for pathogen use could be considered. In addition to the use of commercially available biopesticides, it may be useful to consider employing native entomopathogens. Surveys should be undertaken in different agro-ecological zones to identify prevailing environmental conditions and the presence of native pathogens and natural enemies that may be better suited for the targeted location than an exotic species or strain (Dolinski \& Moino Jr. 2006). On the other hand, an exotic pest may require importation of natural enemies from its native range. In classical biological control, natural enemies, including entomopathogens, are sought in the region of origin of the invasive pest, imported and established in an area where they do not naturally occur. Typically this is a geographic area where the pest has invaded without its natural enemies and there are no effective native natural enemies in the invaded region.

When microbial control agents are formulated as biopesticides, they are predominantly used for inundative applications and often treated much like chemicals, with the expectations that they will perform at the same standards. In general, this has not always been possible. On the other hand, there are biological control agents capable of doing what chemicals are not able to do, i.e. EPNs that have a capacity to find their pest host, kill it and reproduce in it. In fact, many entomopathogens have the capacity to reproduce in the host and hence produce secondary inoculum able to attack and kill other individuals in the pest population. This numerical increase response, of which chemicals are incapable, needs to be better exploited in tropical conditions. Several other advantages of entomopathogens over chemicals are presented by Alves (1998c), Lacey et al. (2001) and Kaya \& Lacey (2007).

The cost of producing natural enemies must be judged in terms of the value of the crop protected by using the agent and in comparison to the cost of competing control options such as chemicals (van Driesche \& Bellows 1996). In Europe the costs of biological control agents used in protected crops and horticulture have proven to be economic and comparable to chemicals. In Florida, the use of EPNs is an integral part of IPM in citrus indicating that the benefit/cost relationship is positive. There are crops that have few or no registered pesticides and consumers who prefer to buy pesticide-free produce. In those cases, microbial control is strongly supported.

\section{Interaction of Entomopathogens and Other Biological Control Agents}

Parasitoids and predators can interact synergistically/ additively (e.g., enhanced transmission and dispersal of insect pathogens) or antagonistically (e.g., parasitism/infection, predation and competition) with entomopathogens. In most studies examining the interaction between entomopathogens and other natural enemies, the pathogen almost always dictates the population dynamics of other guild members (Brooks 1993, Begon et al. 1999). Most studies indicate the positive nature of these interactions with respect to the control of insect populations (Brooks 1993, Begon et al. 1999, Roy $\&$ Pell 2000). Various studies have shown the capacity of parasitoids to identify and avoid oviposition in hosts infected 
by the different entomopathogen groups (Brooks 1993). This rejection is usually due to visual changes that occur in hosts and/or chemical cues associated with biochemical changes in hosts late during the disease development. As for predators, this does not appear to be true (Wraight 2003, Koppenhöfer \& Grewal 2005). The combination of EPNs with other nematode species, fungi and viruses often results in additive effects on pest mortality, whereas nematode-bacteria interactions range from antagonistic to synergistic (Koppenhöfer \& Grewal 2005).

\section{Interaction of Entomopathogens and Chemical Pesticides}

Unlike parasitoid, entomopathogens are generally compatible with chemical pesticides (Croft 1990). Exceptions include use of several fungicides and most nematicides with entomopathogenic fungi and EPNs, respectively. Certain combinations of entomopathogens with chemical pesticides can be synergistic, such as reported by Quintela \& McCoy (1998) and Koppenhöfer et al. (2000) for sublethal concentrations of imidacloprid and fungi or EPNs, respectively. The economic feasibility of such combinations will depend on how much of each component can be reduced compared with their recommended application rates when they are applied individually. The compatibility of chemical pesticides with arthropod natural enemies will be another consideration when integrating pesticides and entomopathogens into a pest management program.

\section{Ecological Engineering and Manipulation of Environment to Enhance Activity and Persistence of Entomopathogens}

Ecological engineering in the context of biological control and IPM is the manipulation of agricultural habitats to be less favorable for arthropod pests and more attractive to beneficial organisms (Gurr et al. 2004). Under optimal environmental conditions many entomopathogens have the natural ability to cause disease at epizootic levels due to their persistence in the environment and efficient transmission. When an insect pathogen is capable of becoming established in an environment it also has the potential to confer long-term regulation of a pest population.

In order for a disease to become epizootic in an arthropod population three factors are required: presence of the host; presence of the pathogen; and proper environmental conditions (Ignoffo 1985). Habitat manipulation techniques have been employed to optimize environmental conditions to increase entomopathogen (endemic, inoculative release, or inundatively applied) activity and facilitate their persistence. These include augmenting moisture in the habitat and creating habitat refuges such as mulches, hedgerows or grass banks, which maintain soil humidity and temperature favorable to microbial activity, propagation, and survival. Manipulated habitats have also been used to provide host plants for alternate arthropod hosts and nectar sources for parasitoids and other natural enemies.
Microbial agents are susceptible to ultra-violet light, heat, and desiccation, but the effects will vary with the microbial species or strain and habitat. Some are capable of remaining viable for just hours (e.g., non-occluded viruses) or days (e.g. fungal conidia, occluded viruses). Others may persist for months (e.g., EPNs, fungal resting spores) or years (e.g., Paenibacillus spp., fungal resting spores). In addition to habitat manipulation, formulation of pathogens with humectants, nutrient sources, and UV protectants has been used to enhance persistence under field conditions (Burges 1998).

\section{Availability of Entomopathogens as a Limiting Factor}

Factors that favor accelerated growth and use of biopesticides are their improved performance and cost competitiveness in the face of increasing insect resistance to chemical insecticides, environmental hazards and lack of selective chemical pesticides. Recently, major agrochemical companies have taken a greater interest in microbial pesticides. In all, 281 biopesticides were available on the market in 1993, with active ingredients of bacteria, EPNs, fungi, and viruses (Lisansky \& Coombs 1994). Although the market for microbial insecticides is growing, it represents less than $1-1.5 \%$ of the total crop protection market (Lacey et al. 2001).

Many microbial control agents can be produced on artificial media using fairly simple methods and there are potentially ample markets for them. However, the bottleneck in the use of microbial control in many countries is their local production and availability. Although there are successful examples of important pests being controlled with biopesticides, many microbial control agents are not universally available to growers.

\section{Conclusions}

Sustainable agriculture will rely increasingly on alternatives to conventional chemical insecticides for pest management that are environmentally friendly and reduce the amount of human contact with hazardous pesticides. Microbial control of arthropod pests of tropical fruits, in conjunction with other IPM components, can provide effective control. The challenge will be to find successful combinations of entomopathogens, predators, and parasitoids along with other interventions. Aspects that warrant further study and attention are improved formulation, storage, marketing, and transfer of technology to growers.

\section{Aknowledgments}

Authors are grateful to Flávio Moscardi, Roberto Pereira, Robin Stuart and Bernhard Zelazny for review of the manuscript and for providing helpful suggestions. Thanks are also due to Robin Stuart, Bernhard Zelazny, Guan Xiong, Jorge Peña, Sérgio Alves and Daniel Sosa-Gómez who contributed literature and/or photographs. 


\section{References}

Agência Nacional de Vigilância Sanitária - ANVISA. 2004. www. anvisa.gov.br. Acessado em Janeiro 2007.

Akhurst, R. \& K. Smith. 2002. Regulation and safety, p.311-332. In R. Gaugler (ed.), Entomopathogenic nematology. New York, CABI Publishing, 388p.

Alfiler, A.R.R. 1992. Current status of the use of a baculovirus in Oryctes rhinoceros control in the Philippines, p. 261-268. In T.A. Jackson \& T.R. Glare (eds.), Use of pathogens in scarab pest management. Andover, Intercept, 298p.

Alves, S.B. (ed.) 1998a. Controle microbiano de insetos. 2nd ed. Piracicaba, Brasil, Fundação de Estudos Agrários Luiz de Queiroz, 1163p.

Alves, S.B. 1998b. Fungos entomopatogênicos, p.289-381. In S.B. Alves (ed.), Controle microbiano de insetos. Piracicaba, Brasil, Fundação de Estudos Agrários Luiz de Queiroz, 1163p.

Alves, S.B. 1998c. Patologia e controle microbiano: Vantagens e desvantagens, p.21-37. In S.B. Alves (ed.), Controle microbiano de insetos. Piracicaba, Brasil, Fundação de Estudos Agrários Luiz de Queiroz, 1163p.

Alves, S.B., A. Moino Jr. \& J.E.M. Almeida. 1998. Desenvolvimento, potencial de uso e comercialização de produtos microbianos, p.1143-1163. In S.B. Alves (ed.), Controle microbiano de insetos. Piracicaba, Brasil, Fundação de Estudos Agrários Luiz de Queiroz, 1163p.

Alves, S.B, M.A. Tamai, L.S. Rossi \& E. Castiglioni. 2005. Beauveria bassiana pathogenicity to the citrus rust mite Phyllocoptruta oleivora. Exp. Appl. Acarol. 37: 117-122.

Alves, S.B., R.M. Pereira, R.B. Lopes \& M.A. Tamai. 2002. Use of entomopathogenic fungi in Latin America, p.193-211. In R.K. Upadhyay (ed.), Advances in microbial control of insect pests. Dordrecht, The Netherlands, Kluwer Academic Publishers, 340p.

Bailez, O.E., A.M. Viana-Bailez, J.O.G. Lima \& D.D.O Moreira. 2003. Life-history of the guava weevil, Conotrachelus psidii Marshall (Coleoptera: Curculionidae), under laboratory conditions. Neotrop. Entomol. 32: 203-207.

Batista Filho, A., L.G. Leite, A. Raga, M.E. Sato \& J.A. Oliviera. 1995. Utilização de Beauveria bassiana (Balls.) Vuill. no manejo de Cosmopolites sordidus Germar, 1824, em Miracatu, SP. Biológico 57: 17-19.

Beattie, G.A., V. Somsook, D.M. Watson, A.D. Clift \& L. Jiang. 1995. Field evaluation of Steinernema carpocapsae (Weiser) (Rhabditida: Steinernematidae) and selected pesticides and enhancers for control of Phyllocnistis citrella Stainton (Lepidoptera: Gracillariidae). J. Austr. Entomol. Soc. 34: 335-342.

Beavers, J.B. \& C.O. Calkins. 1984. Susceptibility of Anastrepha suspensa (Diptera: Tephritidae) to steinernematid and heterorhabditid nematodes in laboratory studies. Environ. Entomol. 13: 137-139.

Bedford, G.O. 1980. Biology, ecology, and control of palm rhinoceros beetles. Annu. Rev. Entomol. 25: 309-339.

Bedford, G.O. 1981. Control of rhinoceros beetle by Baculovirus, p. 409-426. In H.D. Burges (ed.), Microbial control of pests and plant diseases 1970-1980. London, UK, Academic Press, 949p.

Begon, M., S.M. Sait \& D.J. Thompson. 1999. Host-pathogenparasitoid systems, p. 327-348. In B. A. Hawkins and H. V. Cornell (eds.), Theoretical approaches to biological control. Cambridge, Cambridge University Press, 424p.

Boscán de Martinez, N. \& R. Cásares. 1980. El gorgojo de la guayaba Conotrachelus psidii Marshal (Coleoptera: Curculionidae). I. Evaluacion de daños. Agro Tropic30: 77-83.

Boscán de Martinez, N. \& R. Cásares. 1982. Distribuicion en el tiempo de las fases del gorgojo de la guayaba Conotrachelus psidii Marshall (Coleoptera: Curculionidae) en el campo. Agro Tropic 31: 123-130.

Briceno, A.J. 1997. Perspectivas de un manejo integrado del gusano verde del platano, Opsiphanes tamarindi Felder (Lepidoptera: Brassolidae). Rev. Fac. Agron. Universidad del Zulia 14: 487-495.

Brooks, W.M. 1993. Host-parasitoid-pathogen interactions, p.231272. In N.E. Beckage, S.N. Thompson \& B.A. Federici (eds.), Parasites and pathogens of insects. Vol. 2, Pathogens. San Diego, Academic Press, 294p.

Bullock, R.C., R.R. Pelosi \& E.E. Killer. 1999. Management of citrus root weevils (Coleoptera: Curculionidae) on Florida citrus with soil-applied entomopathogenic nematodes (Nematoda: Rhabditida). Fla. Entomol. 82: 1-7.

Burges, H.D. 1998. Formulation of Microbial Biopesticides: Beneficial Microorganisms, Nematodes and Seed Treatments. Dordrecht, Kluwer Academic Publishers, 412p.

Cabrera, R.I., D. Domínguez \& J.J. Blanco. 1987. Informe sobre Hirsutella nodulosa, enemigo natural del acaro blanco Polyphagotarsonemus latus. Comun. Cien. Tech. Agr. Citr. Frutales 10: 135-138.

Castillo, M.A., P. Moya, E. Hernandez \& E. Primo-Yufera. 2000. Susceptibility of Ceratitis capitata Wiedemann (Diptera: Tephritidae) to entomopathogenic fungi and their extracts. Biol. Control 19: 274-282.

Childers, C.C., J.V. French, \& J.C. Rodrigues. 2003. Brevipalus californicus, B. obovatus, B. phoenicis and B. lewisi (Acari: Tenuipalpidae): a review of their biology, feeding injury and economic importance. Exp. Appl. Acarol. 30: 5-28.

Cory, J.S. \& H.F. Evans. 2007. Viruses, p. 149-174. In L.A. Lacey \& H.K. Kaya (eds.), Field manual of techniques in invertebrate pathology: Application and evaluation of pathogens for control of insects and other invertebrate pests, $2^{\text {nd }}$ edition. Dordrecht, Springer Scientific Publishers, 855p.

Croft, B.A. 1990. Arthropod Biological Control Agents and Pesticides. New York, Wiley \& Sons., 723p.

Denholm, I. \& M.W. Rolland. 1992. Tactics for managing pesticide resistance in arthropods: Theory and practice. Annu. Rev. 
Entomol. 37: 92-112.

Dent, D. 2000. Insect pest management. $2^{\text {nd }}$ edition, Ascot, CABI Publishing, 399p.

Dias, C., P. Garcia, N. Simões \& L. Oliveira. 2005. Efficacy of Bacillus thuringiensis against Phyllocnistis citrella (Lepidoptera: Phyllocnistidae). J. Econ. Entomol. 98: 18801883.

Dimbi, S., N.K. Maniania, S.A. Lux, S. Ekesi \& J.K. Mueke. 2003a. Pathogenicity of Metarhizium anisopliae (Metsch.) Sorokin and Beauveria bassiana (Balsamo) Vuillemin, to three adult fruit fly species: Ceratitis capitata (Weidemann), C. rosa var. fasciventris Karsch and C. cosyra (Walker) (Diptera: Tephritidae). Mycopathologia 156: 375-382.

Dimbi, S., N.K. Maniania, S.A. Lux \& J.M. Mueke. 2003b. Host species, age and sex as factors affecting the susceptibility of the African tephritid fruit fly species, Ceratitis capitata, C. cosyra and $C$. fasciventris to infection by Metarhizium anisopliae. Anz. Schaedlkd. 76: 113-117.

Dolinski, C. 2006. Developing a research and extension program for control of the guava weevil in Brazil using entomopathogenic nematodes. J. Nematol. 38: 270.

Dolinski, C. \& A. Moino Jr. 2006. Utilização de nematóides entomopatogênicos nativos ou exóticos: O perigo das introduções. Nematol. Bras. 30: 139-149.

Dolinski, C.M., E.E. del Valle \& R. Stuart. 2006. Virulence of entomopathogenic nematodes to larvae of the guava weevil Conotrachelus psidii (Coleoptera: Curculionidae) in laboratory and greenhouse experiments. Biol. Control 38: 422-427.

Downing, A.S., C.G. Erickson \& M.J. Kraus. 1991. Field evaluation of entomopathogenic nematodes against citrus root weevils (Coleoptera: Curculionidae) in Florida citrus. Fla. Entomol. 74: 584-586.

Driesche, V.R.G. van \& T.S. Bellows Jr. 1996. Biological control. New York, Chapman \& Hall, 539p.

Ekesi, S., N.K. Maniania \& S.A. Lux. 2002. Mortality in three African tephritid fruit fly puparia and adults caused by the entomopathogenic fungi, Metarhizium anisopliae and Beauveria bassiana. Biocontrol Sci. Technol. 12: 7-17.

Ekesi, S., N.K. Maniania \& S.A. Lux. 2003. Effect of soil temperature and moisture on survival and infectivity of Metarhizium anisopliae to four tephritid fruit fly puparia. J. Invertebr. Pathol. 83: 157-167.

Ekesi, S., N.K. Maniania, S.A. Mohamed \& S.A. Lux . 2005. Effect of soil application of different formulations of Metarhizium anisopliae on African tephritid fruit flies and their associated endoparasitoids. Biol. Control 35: 83-91.

El-Choubassi, W., M.A. Iparraguirre-Cruz, M.L. Sisne-Luis \& H. Grillo-Ravelo. 2001. Incidencia del genero Aschersonia sobre la población de Parlatoria ziziphi (Lucas) (Homoptera: Diaspididae) en naranjo Valencia (Citrus sinensis) de la provincia de Ciego de Avila. Centro Agricola 28: 42-45.

Elizondo, J.M. \& J.R. Quezada. 1990. Identificación y evaluación de los enemigos naturales de la mosca prieta de los citricos Aleurocanthus woglumi Ashby (Homoptera: Aleyrodidae) en cuatro zonas citricolas de Costa Rica. Turrialba 40: 190-197.

Faria, M. \& S.P. Wraight. 2001. Biological control of Bemisia tabaci with fungi. Crop Prot. 20: 767-778.

Fawcett, H.S. 1944. Fungus and bacterial diseases of insects as factors in biological control. Botan. Rev. 10: 327-348.

Fazolin, M. 2001. Reconhecimento e manejo integrado das principais pragas da cultura do abacaxi no Estado do Acre. Embrapa Acre. Documentos no 62, 26p.

Figueroa, W. 1990. Biocontrol of the banana root borer weevil, Cosmopolites sordidus (Germar), with steinernematid nematodes. J. Agric. Univ. Puerto Rico 74: 15-19.

Fransen, J.J. 1990. Natural enemies of whiteflies: Fungi, p.187-210. In D. Gerling, (ed.), Whiteflies: Their bionomics, pest status and management. Andover, UK, Intercept, 348p.

Fritsch, E. 1988. Biologische bekampfung des falschen apfelwicklers, Cryptophlebia leucotreta (Meyrick) (Lep., Tortricidae), mit granuloseviren. Mitt. Dtsch. Ges. Allg. Ang. Entomol. 6: 280-283.

Gao, R.X., Z. Ouyang, Z.X. Gao \& J.X. Zheng. 1985. A preliminary report on the application of Aschersonia aleyrodis for the control of citrus whitefly. Chinese J. Biol. Control 1: 45-46. (in Chinese).

Gazit, Y., Y. Rössler, \& I. Glazer. 2000. Evaluation of entomopathogenic nematodes for the control of Mediterranean fruit fly (Diptera: Tephritidae). Biocontrol Sci. Technol. 10: 157-164.

Georgis, R., A.M. Koppenhöfer, L.A. Lacey, G. Bélair, L.W. Duncan, P.S. Grewal, M. Samish, L. Tan, P. Torr \& R.W.H.M. van Tol. 2006. Successes and failures in the use of parasitic nematodes for pest control. Biol. Control 38: 103-123.

Giblin-Davis, R.M., J.E. Peña \& R.E. Duncan. 1994. Lethal pitfall trap for evaluation of semiochemical-mediated attraction of Metamasius hemipterus sericeus (Coleoptera: Curculionidae). Fla. Entomol. 77: 247-255.

Giblin-Davis, R.M., J.E. Peña \& R.E. Duncan. 1996. Evaluation of an entomopathogenic nematode and chemical insecticides for control of Metamasius hemipterus sericeus (Coleoptera: Curculionidae). J. Entomol. Sci. 31: 240-251.

Godonou, I., K.R. Green, K.A. Oduro, C.J. Lomer \& K. AfrehNuamah. 2000. Field evaluation of selected formulations of Beauveria bassiana for the management of the banana weevil (Cosmopolites sordidus) on plantain (Musa spp., AAB Group). Biocontrol Sci. Technol. 10: 779-788.

Goettel, M.S., J. Eilenberg \& T.R. Glare. 2005. Entomopathogenic fungi and their role in regulation of insect populations, p.361406. In L.I. Gilbert, K. Iatrou and S. Gill (eds.), Comprehensive molecular insect science, v. 6. Oxford, Elsevier Pergamon, $470 \mathrm{p}$.

Gold, C.S., B. Pinese \& J.E. Peña. 2002. Pests of banana, p. 13-56. In J.E. Peña, J.L. Sharp \& M. Wysoki (eds.), Tropical fruit 
pests and pollinators: Biology, economic importance, natural enemies, and control. Wallingford, UK, CABI Publishing, $448 \mathrm{p}$.

Gold, C.S., C. Nankinga, B. Niere \& I. Godonou. 2003. IPM of banana weevil in Africa with emphasis on microbial control, p. 243-257. In P. Neuenschwander, C. Borgemeister \& J. Langewald (eds.), Biological control in IPM systems in Africa. Wallingford, UK, CABI Publishing, 400p.

Gold, C.S., J.E. Peña \& E.B. Karamura. 2001. Biology and integrated pest management for the banana weevil Cosmopolites sordidus (Germar) (Coleoptera: Curculionidae). Int. Pest Manage. Rev. 6: $79-155$.

Gopalakrishnan, C. \& P.N. Gangavisalakshy. 2005. Field efficacy of commercial formulations of Bacillus thuringiensis var. kurstaki against Papilio demoleus L. on citrus. Entomon 30: 93-95.

Gould, W.P. \& A. Raga. 2002. Pests of guava, p.295-313. In J.E. Peña, J.L. Sharp \& M. Wysoki (eds.), Tropical fruit pests and pollinators. Wallingford, UK, CABI Publishing, 400p.

Graham, J.H., D.B. Bright \& C.W. McCoy. 2003. PhytophthoraDiaprepes weevil complex: Phytophthora spp. relationship to citrus rootstocks. Plant Dis. 87: 85-90.

Gravena, S., R.R. Leão-Neto, F.C. Moretti \& G. Tozatti. 1988. Eficiência de inseticidas sobre Selenaspidus articulatus (Morgan) (Homoptera, Diaspididae) e efeito sobre inimigos naturais em pomar citrico. Científica 16: 209-217.

Grim, C \& F. Guharay. 1998. Control of leaf-footed bug Leptoglossus zonatus and shield-backed bug Pachycoris klugii with entomopathogenic fungi. Biocontrol Sci. Tech. 8: 356-376.

Gurr, G.M., S.L. Scarrat, S.D. Wratten, L. Berndt \& N. Irvin. 2004. Ecological engineering, habitat manipulation and pest management, p.1-12. In G.M. Gurr, S.D. Wratten, \& M.A. Altieri \& D. Pimentel (eds.), Ecological engineering for pest management: Advances in habitat manipulation for arthropods. Collingwood, Australia, CSIRO Publishing, 232p.

Hirt, R.P., J.M. Logsdon Jr., B. Healy, M.W. Dorey, W.F. Doolittle \& T.M. Embley. 1999. Microsporidia are related to fungi: Evidence from the largest subunit of RNA polymerase II and other proteins. Proc. Natl. Acad. Sci. USA 96: 580-585.

Hokkanen, H.M.T. \& A.E. Hajek (eds.). 2003. Environmental impacts of microbial insecticides: Need and methods for risk assessment. Dordrecht, Kluwer Academic Publishers, 269p.

Huffaker, C.B. 1985. Biological control in integrated pest management: An entomological perspective, p.13-23. In M.A. Hoy \& D.C. Herzog (eds.), Biological control in agricultural IPM systems. San Diego, CA, Academic Press, 589p.

Huger, A.M. 1966. A virus disease of the Indian rhinoceros beetle Oryctes rhinoceros caused by a new type of insect virus Rhabdinovirus oryctes gen. n., sp. n. J. Invertebr. Pathol. 8: 38-51.

Huger, A.M. 1973. Grundlagen zur biologischen Bekämpfung des Indischen Nashornkäfers, Oryctes rhinoceros (L.), mit Rhabdionvirus oryctes: Histopathologie der Virose bei Kafern.
Zeitschr. Angew. Entomol. 72: 309-319.

Huger, A.M. 2005. The Oryctes virus: Its detection, identification, and implementation in biological control of the coconut palm rhinoceros beetle, Oryctes rhinoceros (Coleoptera: Scarabaeidae). J. Invertebr. Pathol. 89: 78-84.

Humber, R. 1997. Fungi: Identification, p.153-185. In L.A. Lacey (ed.), Manual of techniques in insect pathology. London, Academic Press, 409p.

Hunter-Fujita, F.R., P.F. Entwistle, H.F. Evans \& N.E. Crook. 1998. Insect viruses and pest management. Chichester, John Wiley \& Sons, 632p.

Ignoffo, C.M. 1985. Manipulating enzootic-epizootic diseases of arthropods, p.243-262. In M.A. Hoy \& D.C. Herzog (eds.), Biological control in agricultural IPM systems. San Diego, Academic Press, 589p.

Inglis, G.D., M.S. Goettel, T.M. Butt \& H. Strasser. 2001. Use of hyphomycetous fungi for managing insect pests, p.27-69. In T.M. Butt, C. Jackson \& N. Magan (eds.), Fungi as biocontrol agents: Progress, problems and potential. Wallingford, UK, CABI Publishing, 350.

Jackson, T.A., A.M. Crawford \& T.R. Glare. 2005. Oryctes virus - time for a new look at a useful biocontrol agent. J. Invertebr. Pathol. 89: 91-94.

Jackson, T.A. \& T.R. Glare (eds.). 1992. Use of pathogens in scarab pest management, Andover, Intercept, 298p.

Jones, K.A., B. Zelazny, U. Ketunuti, A. Cherry \& D. Grzywacz. 1998. South-east Asia and the western Pacific, p.244-257. In F.R. Hunter-Fujita, P.F. Entwistle, H.F. Evans \& N.E. Crook (eds.), Insect viruses and pest management. Chichester, J. Wiley \& Sons, 620p.

Joubert, P.H. \& T.I. Labuschagne. 1995. Alternative measures for controlling mango seed weevil, Sternochetus mangiferae (F.). Yearbook S. Afr. Mango Grow. Assoc. 15: 94-96.

Kaya, H.K. \& L.A. Lacey. 2007. Introduction to microbial control, p.3-7. In L.A. Lacey \& H.K. Kaya (eds.), Field manual of techniques in invertebrate pathology: application and evaluation of pathogens for control of insects and other invertebrate pests, $2^{\text {nd }}$ edition. Dordrecht, Springer Scientific Publishers, 855p.

Kaya, H.K. \& R.Gaugler. 1993. Entomopathogenic nematodes. Annu. Rev. Entomol. 38: 181-206.

Kaya, H.K. \& S.P. Stock. 1997. Techniques in insect nematology, p.281-324. In L. A. Lacey, (ed.), Manual of techniques in insect pathology, Academic Press, London. 409 p.

Kermarrec, A. \& H. Mauleon. 1989. Synergie entre le chlordecone et Neoaplectana carpocapsae Weiser (Nematoda; Steinernematidae) pour le controle de Cosmopolites sordidus (Coleoptera: Curculionidae). Rev. Nematol. 12: 324-324.

Klein, M.G., P.S. Grewal, T.A. Jackson \& A.M. Koppenhöfer. 2007. Lawn, turf and grassland pests, p.655-675. In L.A. Lacey \& H.K. Kaya (eds.), Field manual of techniques in invertebrate pathology: Application and evaluation of pathogens for control 
of insects and other invertebrate pests, $2^{\text {nd }}$ edition. Dordrecht, Springer Scientific Publishers, 855p.

Konstantopoulou, M.A. \& B.E. Mazomenos. 2005. Evaluation of Beauveria bassiana and B. brongniartii strains and four wildtype fungal species against adults of Bactrocera oleae and Ceratitis capitata. BioControl 50: 293-305.

Koppenhöfer, A.M., I.M. Brown, R. Gaugler, P.S. Grewal, H.K. Kaya \& M.G. Klein. 2000. Synergism of entomopathogenic nematodes and imidacloprid against white grubs: Greenhouse and field evaluation. Biol. Control 19: 245-251.

Koppenhöfer, A.M. \& P.S. Grewal. 2005. Compatibility and interaction with agrochemicals and other biocontrol agents, p.363-381. In P.S. Grewal, R.-U. Ehlers \& D.I. ShapiroIlan (eds), Nematodes as biocontrol agents. Ascot, CABI Publishing, 505p.

Laborda, R., L. Bargues, C. Navarro, O. Barajas, M. Arroyo, E.M., Garcia, E. Montoro, E. Llopis, A. Martinez \& J.M. Sayagues. 2003. Susceptibility of the Mediterranean fruit fly (Ceratitis capitata) to entomopathogenic nematode Steinernema spp. (“Biorend C"). Bull. OILB/SROP 26: 95-97.

Lacey, L.A., J.J. Fransen \& R. Carruthers. 1996. Global distribution of naturally occurring fungi of Bemisia, their biologies and use as biological control agents, p.401-433. In D. Gerling \& R. Mayer (eds.), Bemisia 1995: Taxonomy, biology, damage, control and management. Andover, Intercept, 702p.

Lacey, L.A. \& J.P. Siegel. 2000. Safety and ecotoxicology of entomopathogenic bacteria, p.253-273. In J.-F. Charles, A. Delécluse \& C. Nielsen-LeRoux (eds.), Entomopathogenic bacteria: From laboratory to field application. Dordrecht, Kluwer Academic Publishers, 524p.

Lacey, L.A., R. Frutos, H. K. Kaya \& P. Vail. 2001. Insect pathogens as biological control agents: do they have a future? Biol. Control 21: 230-248.

Laird, M., L.A. Lacey \& E.W. Davidson, (eds.). 1990. Safety of microbial insecticides. Boca Raton, CRC Press, 259p.

Latgé, J.P. \& B. Papierok. 1988. Aphid pathogens, p.323-335. In A.K. Minks \& P. Harrewijn, (eds.), Aphids their biology, natural enemies and control, v. B. Amsterdam, Elsevier Science \& Technology, 322p.

Leite, L.G., F.M. Tavares, R.M. Goulart, A. Batista Filho \& J.R.P. Parra. 2005. Patogenicidade de nematóides entomopatogênicos a larvas de $6^{\circ}$ instar do bicho-furão, Ecdytolopha aurantiana (Lepidoptera: Tortricidae), e avaliação de dosagens de Heterorhabditis indica na mortalidade do inseto. Rev. Agric. 80: 316-330.

Lezama-Gutiérrez, R., O.J. Molina, O.L. Contreras-Ochoa, M. Gonzáles-Ramírez, A. Trujillo-de la Luz \& O. RebolledoDomínguez. 1996. Susceptibilidad de larvas de Anastrepha ludens (Diptera: Tephritidae) a diversos nemátodos entomopatógenos (Steinernematidae y Heterorhabditidae). Vedalia 3: 31-33.

Lezama-Gutiérrez, R., A. Trujillo de la Luz, J. Molina-Ochoa, O. Rebolledo-Dominguez, A. R. Pescador, M. Lopez-Edwards
\& M. Aluja. 2000. Virulence of Metarhizium anisopliae (Deuteromycotina: Hyphomycetes) on Anastrepha ludens (Diptera: Tephritidae): laboratory and field trials. J. Econ. Entomol. 93: 1080-1084.

Lindegren, J.E. \& P.V. Vail. 1986. Susceptibility of Mediterranean fruit fly, melon fly, and oriental fruit fly (Diptera: Tephritidae) to the entomogenous nematode Steinernema feltiae in laboratory tests. Environ. Entomol. 15: 465-468.

Lindegren, J.E., T.T. Wong \& D.O. McInnis. 1990. Response of Mediterranean fruit fly (Diptera: Tephritidae) to the entomogenous nematode Steinernema feltiae in field tests in Hawaii. Environ. Entomol. 19: 383-386.

Lisansky, S.G. \& J. Coombs. 1994. Developments in the market for biopesticides. Brighton Crop Protection Conference-Pests and Diseases, v. 3, 1049-1054.

Lomer, C.J. 1986. Release of Baculovirus Oryctes into Oryctes monoceros populations in the Seychelles. J. Invertebr. Pathol. 47: 237-24.

Lomer, C.J. 1987. Infection of Strategus aloeus (L.) (Coleoptera: Scarabaeidae) and other Dynastinae with Baculovirus Oryctes. Bull. Entomol. Res. 77: 45-51.

Lorenzato, D., E.C. Chouene, J. Medeiros, A.E.C. Rodrigues \& R.C.D. Pederzolli. 1997. Ocorrência e controle da brocado-fruto-do-abacaxi Thecla basalides (Geyer, 1837). Pesq. Agropec. Gaúcha 3: 15-19.

Marschall, K.J. \& I. Ioane. 1982. The effect of re-release of Oryctes rhinoceros baculovirus in the biological control of rhinoceros beetles in Western Samoa. J. Invertebr. Pathol. 39: 267-276.

Masarrat, H. \& R.P. Srivastava. 1998. Dose-mortality relationship of entomogenous fungus, Beauveria bassiana (Bals.) Vuill. against mango mealy bug, Drosicha mangiferae (Green). Insect Environ. 4: 74-75.

McCoy, C.W. 1996. Pathogens of eriophyoid mites, p.481-490. In E.E. Linquist, M.W. Sabelis \& J. Bruim (eds.), Eriophyoid mites. Their biology, natural enemies and control. Amsterdam, Elsevier Press, 820p.

McCoy, C.W., A.G. Selhime, R.F. Kanavel \& A.J. Hill. 1971. Suppression of citrus rust mite populations with application of fragmented mycelia of Hirsutella thompsonii. J. Invertebr. Pathol. 17: 270-276.

McCoy, C.W., R.A. Samson. \& D.G. Boucias. 1988. Entomogenous fungi, p.151-236. In C.M. Ignoffo \& N.B. Mandava (eds.), Handbook of natural pesticides, v. V: Microbial insecticides, Part A: Entomogenous protozoa and fungi. Boca Raton, Fl, CRC Press, 260p.

McCoy, C.W., R.J. Stuart, D.I. Shapiro-Ilan \& L.W. Duncan. 2007. Application and evaluation of entomopathogens for citrus pest control, p.567-581. In L.A. Lacey \& H.K. Kaya (eds.), Field manual of techniques in invertebrate pathology: Application and evaluation of pathogens for control of insects and other invertebrate pests, $2^{\text {nd }}$ Edition. Dordrecht, Springer Scientific Publishers, 855p.

McCoy, C.W., R.J. Stuart, L.W Duncan \& K. Nguyen. 2002. Field 
efficacy of two commercial preparations of entomopathogenic nematodes against larvae of Diaprepes abbreviatus (Coleoptera: Curculionidae) in alfisol type soil. Fla. Entomol. 85: 537544.

McCoy, C.W. \& T.L. Couch. 1982. Microbial control of the citrus rust mite with the mycoacaricide, Mycar. Fla. Entomol. 65: 116-126.

Meyerdirk, D.E., J.B. Kreasky \& W.G. Hart. 1980. Whiteflies (Aleyrodidae) attacking citrus in southern Texas with notes on natural enemies. Can. Entomol. 112: 1253-1258.

Mochi, D.A., A.C. Monteiro, S.A. De Bortoli, H.O.S. Dória \& J.C. Barbosa. 2006. Pathogenicity of Metarhizium anisopliae for Ceratitis capitata (Wied.) (Diptera: Tephritidae) in soil with different pesticides. Neotrop. Entomol. 35: 382-389.

Mohan, S., A. Sirohi \& H.S. Gaur. 2004. Successful management of mango mealy bug, Drosicha mangiferae by Photorhabdus luminescens, a symbiotic bacterium from entomopathogenic nematode Heterorhabditis indica. Int. J. Nematol. 14: 195198.

Monsarrat, P. \& J.C. Veyrunnes. 1976. Evidence of Oryctes virus in adult feces and new data for virus characterization. J. Invertebr. Pathol. 27: 387-389.

Moore, S.D. 2002. Entomopathogens \& microbial control of citrus pests in South Africa: A review. SA Fruit J. 1: 30-32.

Moore, S.D., T. Pittaway, G. Bouwer \& J.G. Fourie. 2004. Evaluation of Helicoverpa armigera nucleopolyhedrovirus (HearNPV) for control of Helicoverpa armigera (Lepidoptera: Noctuidae) on citrus in South Africa. Biocontrol Sci. Technol. 14: $239-250$.

Moore, S., W. Kirkman \& P. Stephen. 2005. CRYPTOGRAN: a virus for the biological control of false codling moth. SA Fruit J. 3: 35-39.

Morse, J.G. \& J.E. Lindegren. 1996. Suppression of Fuller rose beetle on citrus with Steinernema carpocapsae. Fla. Entomol. 79: 373-384.

Morton, J.F. 1987a. Papaya, p.336-346. In J.F. Morton (ed.), Fruits of warm climates. Miami, Florida Flair Books, 505p.

Morton, J. 1987b. Pineapple, p.18-28. In J.F. Morton (ed.), Fruits of warm climates. Miami, Florida Flair Books, 505p

Moscardi, F. 1999. Assessment of the application of baculoviruses for the control of Lepidoptera. Annu. Rev. Entomol. 44: 257289.

Narayanamma, V.L. \& P. Savithri. 2003. Evaluation of biopesticides against citrus butterfly, Papilio demoleus L. on sweet orange. Indian J. Plant Prot. 31: 105-106.

Pantoja, A., P.A. Follett \& J.A. Villanueva-Jiménez. 2002. Pests of papaya, p.131-156. In J.E. Peña, J.L. Sharp \& M. Wysoki (eds.), Tropical fruit pests and pollinators: Biology, economic importance, natural enemies, and control. Wallingford, UK, CABI Publishing, 440p.

Peña, J.E., A.I. Mohyuddin \& M. Wysoki. 1998. A review of the pest management situation in mango agroecosystems.
Phytoparasitica 26: 1-20.

Peña, J.E., D.G. Hall \& C.W. McCoy. 2000. Natural enemies of the weevil Diaprepes abbreviatus (Coleoptera: Curculionidae), a serious pest of citrus in Florida. Proc. Intl. Soc. Citriculture 2: 785-788.

Peña, J.E. \& F.A. Johnson. 2006. Insect management in papaya. Univ. Florida Coop. Ext. Serv. Pub. ENY-414, 5 p. http://edis. ifas.ufl.edu/BODY_IG074

Peña, J.E., L.S. Osborne \& R.E. Duncan. 1996. Potential of fungi as biocontrol agents of Polyphagotarsonemus latus (Acari: Tarsonemidae). Entomophaga 41: 27-36.

Peña, J.E., R.M. Baranowski \& R.E. Litz. 1987. Life history, behavior and natural enemies of Philephedra tuberculosa (Homoptera: Coccidae). Fla. Entomol. 70: 423-427.

Peña, J.E., R.M. Gilbin-Davis \& R. Duncan. 1995. Impact of indigenous Beauveria bassiana (Balsamo) Vuillemin on banana weevil and rotten sugarcane weevil (Coleoptera: Curculionidae) populations in banana in Florida. J. Agric. Entomol. 12: 163-167.

Peña, J.E., W.J. Schroeder \& L.S. Osborne. 1990. Use of entomopathogenic nematodes in the families Heterorhabditidae and Steinernematodae to control banana moth (Opogona sachari). Nematropica 20: 51-55.

Petty, G.J., G.R. Stirling \& D.P. Bartholomew. 2002. Pests of pineapple, p.157-195 In J. Peña, J. Sharp \& M. Wysoki (eds.), Tropical fruit pests and pollinators: Biology, economic importance, natural enemies and control. Wallingford, UK, CABI Publishing, 440p.

Ponomarenko, N.G., H.A. Prilepskaya, M.Y. Murvanidze \& L.A. Stolyarova. 1975. Aschersonia against whiteflies. Zashch. Rast. 6: 44-45.

Poprawski, T.J., P.E. Parker \& J.H. Tsai. 1999. Laboratory and field evaluation of hyphomycete insect pathogenic fungi for control of brown citrus aphid. Environ. Entomol. 28: 315-321.

Purrini, K. 1989. Baculovirus oryctes release into Oryctes monoceros population in Tanzania, with special reference to the interaction of virus isolates used in our laboratory infection experiments. J. Invertebr. Pathol. 53: 285-300.

Quezada, J.R. 1974. Biological control of Aleurcanthus woglumi (Homoptera: Aleyrodidae) in El Salvador. Entomophaga 19: 243-254.

Quintela, E.D. \& C.W. McCoy. 1998. Synergistic effect of imidacloprid and two entomopathogenic fungi on the behavior and survival of larvae of Diaprepes abbreviatus in soil. J. Econ. Entomol. 91: 110-122.

Ramle, M., M.B.Wahid, K. Norman, T.R.Glare \& T.A. Jackson. 2005. The incidence and use of Oryctes virus for control of rhinoceros beetle in oil palm plantations in Malaysia. J. Invertebr. Pathol. 89: 85-90.

Reed, R.K. 1981. Control of mites by non-occluded viruses, p.427432. In H.D. Burges (ed.), Microbial control of pests and plant diseases 1970-1980. New York, Academic Press, 949p. 
Rosa, W. de la, F.L. Lopez \& P. Liedo. 2002. Beauveria bassiana as a pathogen of the Mexican fruit fly (Diptera: Tephritidae) under laboratory conditions. J. Econ. Entomol. 95: 36-43.

Rosales, L.C. \& H.Z. Suarez. 1998. Nematodos entomopatogenos como posibles agentes de control del gorgojo negro del platano Cosmopolites sordidus (Germar 1824) (Coleoptera: Curculionidae). Bol. Entomol. Venezolana Ser. Monograf. 13: $123-140$.

Rossi-Zalaf, L.S. \& S.B. Alves. 2006. Susceptibility of Brevipalpus phoenicis to entomopathogenic fungi. Exp. Appl. Acarol. 40: 37-47.

Roy, H.E. \& J.K. Pell. 2000. Interactions between entomopathogenic fungi and other natural enemies: Implications for biological control. Biocontrol Sci. Technol. 10: 737-752.

Saenz-de-Cabezon, F.J., V. Marco-Mancebón \& I. Pérez-Moreno. 2003. The entomopathogenic fungus Beauveria bassiana and its compatibility with triflumuron: Effects on the twospotted spider mite Tetranychus urticae. Biol. Control 26: 168-173.

Samson, R.A., C. McCoy \& K. O’Donnell. 1980. Taxonomy of the acarine parasite, Hirsutella thompsonii. Mycologia 72: 359-377.

Sanches, N.F. 2005. Manejo integrado da broca-do-fruto do abacaxi. Embrapa Mandioca e Fruticultura Tropical Bol. Tec. $\mathrm{n}^{\circ}$ 36, $37 \mathrm{p}$.

Schoeman, P.S. \& M.H. Schoeman. 1999. Transmission of Beuaveria bassiana from infected adults of the banana weevil Cosmopolites sordidus (Coleoptera: Curculionidae). Afr. Plant Protect. 5: 53-54.

Shapiro, J.P., W.J. Schroeder \& P.A. Stansly. 1998. Bioassay and efficacy of Bacillus thuringiensis and an organosilicone surfactant against the citrus leafminer (Lepidoptera: Phyllocnistidae). Fla. Entomol. 81: 201-210.

Shapiro-Ilan, D.I., L.W. Duncan, L.A. Lacey \& R. Han. 2005. Orchard crops, p.215-229. In P.S. Grewal, R.-U. Ehlers \& D.I. Shapiro-Ilan (eds.), Nematodes as biological control agents. Wallingford, CABI Publishing, 505p.

Shapiro-Ilan, D.I., D.H. Gouge \& A.M. Koppenhöfer. 2002. Factors affecting commercial success: Case studies in cotton, turf and citrus, p.333-355. In R. Gaugler (ed.), Entomopathogenic nematology. Wallingford, CABI Publishing, 388p.

Shaw, J.G., D.L. Chambers \& H. Tashiro. 1968. Introducing and establishing the non-inclusion virus of the citrus red mite in citrus groves. J. Econ. Entomol. 61: 1352-1355.

Shukla, R.P., P.L. Tandon \& S.J. Singh. 1984. Baculovirus-a new pathogen of mango nut weevil, Sternochetus mangiferae (Fabricius) (Coleoptera: Curculionidae). Current Sci. 53: 593-594.

Simpson, S.E., H.N. Nigg, N.C. Coile \& R.A. Adair. 1996. Diaprepes abbreviatus (Coleoptera: Curculionidae): Host plant association. Environ. Entomol. 25: 333-349.

Smith, D. 1995. Banana weevil borer control in south-eastern Queensland. Aust. J. Exp. Agric. 35: 1165-1172.
Smith, D. \& J.E. Peña. 2002. Tropical citrus pests, p.57-101. In J.E. Peña, J.L. Sharp \& M. Wysoki (eds.), Tropical fruit pests and pollinators: biology, economic importance, natural enemies and control. Wallingford, CABI Publishing, 440p.

Smith, D.H., J.V. da Graça \& V.H. Whitlock. 1990. Granulosis virus from Cacoecia occidentalis: Isolation and morphological description of a granulosis virus of the citrus leafroller, Cacoecia occidentalis. J. Invertebr. Pathol. 55: 319-324.

Solter, L.E. \& J.J. Becnel. 2007. Entomopathogenic microsporidia, p.199-221. In L.A. Lacey \& H.K. Kaya (eds.), Field manual of techniques in invertebrate pathology: Application and evaluation of pathogens for control of insects and other invertebrate pests, $2^{\text {nd }}$ edition. Dordrecht, Springer Scientific Publishers, 855p.

Souza, J.C., A. Haga \& M.A. Souza. 2003. Pragas da goiabeira. Boletim Técnico 71. EPAMIG, Minas Gerais, Brazil, 60p.

Srivastava, R.P. \& M. Fasih. 1988. Natural occurrence of Beauveria bassiana, an entomogenous fungus on mango mealy bug, Drosicha mangiferae Green. Indian J. Plant Pathol. 6: 8-10.

Srivastava, R.P. \& P.L. Tandon. 1986. Natural occurrence of two entomogenous fungi pathogenic to mango hopper, Idioscopus clypealis Leth. Indian J. Plant Pathol. 4: 121-123.

Steinkraus, D.C. 2007. Documentation of naturally-occurring pathogens and their impact in agroecosystems, p.267-281. In L.A. Lacey \& H.K. Kaya (eds.), Field manual of techniques in invertebrate pathology: application and evaluation of pathogens for control of insects and other invertebrate pests, $2^{\text {nd }}$ edition. Dordrecht, Springer Scientific Publishers.

Stephens, C.S. 1962. Oiketicus kirbyi (Lepidoptera: Psychidae) a pest of bananas in Costa Rica. J. Econ. Entomol. 55: 381386.

Stuart, R.J., S. Polavarapu, E.E. Lewis \& R. Gaugler. 1997. Differential susceptibility of Dysmicoccus vaccinii (Homoptera: Pseudococcidae) to entomopathogenic nematodes (Rhabditida: Heterorhabditidae and Steinermatidae). J. Econ. Entomol. 90: 925-932.

Syvertsen, J.P. \& C.W. McCoy. 1985. Leaf feeding injury to citrus by root weevil adults: Leaf area, photosynthesis, and water use efficiency. Fla. Entomol. 68: 386-393.

Tarrant, C.A. \& C.W. McCoy. 1989. Effect of temperature and relative humidity on the egg and larval stages of some citrus weevils. Fla. Entomol. 72: 117-123.

Tinzaara, W., C.S. Gold, C. Nankinga, M. Dicke, A. van Huis, P.E. Ragama \& G.H. Kagezi. 2004. Integration of pheromones and the entomopathogenic fungus for the management of the banana weevil. Uganda J. Agric. Sci. 9: 621-629.

Toledo, J., J.E. Ibarra, P. Liedo, A. Gomez, M.A. Rasgado \& T. Williams. 2005. Infection of Anastrepha ludens (Diptera: Tephritidae) larvae by Heterorhabditis bacteriophora (Rhabditida: Heterorhabditidae) under laboratory and field conditions. Biocontrol Sci. Technol. 15: 627-634.

Toledo, J., J.L. Gurgúa, P. Liedo, J.E. Ibarra \& A. Oropeza. 2001. Parasitismo de larvas y pupas de la mosca mexicana de la 
fruta, Anastrepha ludens (Loew) (Diptera: Tephritidae) por el nemátodo Steinernema feltiae (Filipjev) (Rhabditida: Steinernematotidae). Vedalia 8: 27-36.

Toledo, J., M.A. Rasgado, J.E. Ibarra, A. Gomez, P. Liedo \& T. Williams. 2006. Infection of Anastrepha ludens following soil applications of Heterorhabditis bacteriophora in a mango orchard. Entomol. Exp. Applic. 119: 155-162.

Treverrow, N. \& R.A. Bedding. 1993. Development of a system for the control of the banana weevil borer, Cosmopolites sordidus, with entomopathogenic nematodes, p.41-47. In R.A. Bedding, R. Akhurst \& H.K. Kaya (eds.), Nematodes and the biological control of insect pests. Melbourne, CSIRO Publishing, 178p.

Treverrow, N., R.A. Bedding, E.B. Dettmann \& C. Maddox. 1991. Evaluation of entomopathogenic nematodes for control of Cosmopolites sordidus Germar (Coleoptera: Curculionidae), a pest of bananas in Australia. Ann. Appl. Biol. 119: 139-145.

Uchida, M. 1970. Studies on the use of the parasitic fungus Aschersonia sp. for controlling citrus whitefly, Dialeurodes citri. Bull. Kanagawa Hort. Exp. Sta. 18: 66-74. (in Japanese).

Vyas, R.V., J.J. Patel, P.H. Godhani \& D.N. Yadav. 1993. Evaluation of green muscardine fungus (Metarhizium anisopliae var. anisopliae) for control of mangohopper (Amritodus atkinsoni). Indian J. Agric. Sci. 63: 602-603.

Waite, G.K. 2002. Pests and pollinators of mango, p.103-129. In J.E. Peña, J.L. Sharp \& M. Wysoki (eds.). Tropical fruit pests and pollinators: biology, economic importance, natural enemies and control. Wallingford, UK, CABI Publishing, 440p.

Weathersbee, A.A. III, Y.Q.Tang, H. Doostdar \& R.T. Mayer. 2002. Susceptibility of Diaprepes abbreviatus (Coleoptera: Curculionidae) to a commercial preparation of Bacillus thuringiensis subsp. tenebrionis. Fla. Entomol. 85: 330-335.

Weissling, T.J. \& R.M. Giblin-Davis. 1998. Silky cane weevil, Metamasius hemipterus sericeus (Oliver) (Insecta: Coleoptera: Curculionidae: Dryophthorinae). http://edis.ifas.ufl.edu/ IN210

Woodruff, R.E. 1964. A Puerto Rican weevil new to the United States (Coleoptera: Curculionidae). Florida Department of Agriculture. Plant Industry Entomology Circular 77: 1-4.

Wraight, S.P. 2003. Synergism between insect pathogens and entomophagous insects, and its potential to enhance biological control efficacy, p.139-163. In O. Koul \& G.S. Dhaliwal (eds.), Advances in biopesticide research, v. 3, predators and parasitoids. London, Taylor \& Francis Group, 191p.

Yen, D.F. \& Y.T. Tsai. 1969. Entomogenous fungi of citrus Homoptera in Taiwan. Plant Prot. Bull. 11: 1-10.

Young, E.C. 1974. The epizootiology of two pathogens of the coconut palm rhinoceros beetle. J. Invertebr. Pathol. 24: 82-92.
Young, E.C. \& J.F. Longworth. 1981. The epizootiology of the baculovirus of the coconut palm rhinoceros beetle (Oryctes rhinoceros) in Tonga. J. Invertebr. Pathol. 38: 362-369.

Zelazny, B. 1972. Studies on Rhabdionvirus rhinoceros. I. Effects on larvae of Oryctes rhinoceros and inactivation of virus. J. Invertebr. Pathol. 20: 235-241.

Zelazny, B. 1973. Studies on Rhabdionvirus rhinoceros. II. Effects on adults of Oryctes rhinoceros. J. Invertebr. Pathol. 22: 122-126.

Zelazny, B. 1976. Transmission of a Baculovirus in populations of Oryctes rhinoceros. J. Invertebr. Pathol. 27: 221-227.

Zelazny, B. 1977. Oryctes rhinoceros populations and behavior influenced by a baculovirus. J. Invertebr. Pathol. 29: 210-215.

Zelazny, B. 1978. Methods for inoculating and diagnosing the baculovirus disease of Oryctes rhinoceros. FAO Plant Prot. Bull. 26: 163-168.

Zelazny, B. 1983. Oryctes rhinoceros damage on coconut palm in the Maldives. FAO Plant Prot. Bull. 31: 119-120.

Zelazny, B., A. Lolong \& A.M. Crawford. 1990. Introduction and field comparison of baculovirus strains against Oryctes rhinoceros (Coleoptera: Scarabaeidae) in the Maldives. Environ. Entomol. 19: 1115-1121.

Zelazny, B., A. Lolong \& B. Pattang. 1992. Oryctes rhinoceros (Coleoptera: Scarabaeidae) populations suppressed by a baculovirus. J. Invertebr. Pathol. 59: 61-68.

Zelazny, B. \& A.R.R. Alfiler. 1986. Oryctes rhinoceros (Coleoptera: Scarabaeidae) larva abundance and mortality factors in the Philippines. Environ. Entomol. 15: 84-87.

Zelazny, B. \& A.R.R. Alfiler. 1991. Ecology of baculovirusinfected and healthy adults of Oryctes rhinoceros (Coleoptera: Scarabaeidea) on coconut palms in the Philippines. Ecol. Entomol. 16: 253-259.

Zelazny, B., A.R.R. Alfiler \& A. Lolong. 1989. Possibility of resistance to a baculovirus in populations of the coconut rhinoceros beetle (Oryctes rhinoceros). FAO Plant Prot. Bull. 37: $77-82$.

Zelazny, B. \& M. Moezir. 1989. Pengendalian hama kumbang rhinoceros pada tanman kelapa. Berita Perlindungan Tanaman Perkebunan 1: 1-6.

Zhou, Y.S., F.R. Shen \& H.P. Zhao. 1998. Applying Beauveria bassiana to control Rhytidodera bowringii. J. Beijing Forest. Univ. 20: 65-69.

Received 13/11/06 